\title{
Meteoritos no pomar: sobre o potencial construtivo da integração funcional
}

Meteorites in the orchard: on the structuring potential of functional integration

Francisco Zmekhol Nascimento de Oliveira ${ }^{1}$

Universidade Federal de Rondônia (UNIR) franciscodeoliveira@unir.br 


\section{Resumo}

De Monteverdi a Mahler, R. Strauss e o jovem Schoenberg, a tonalidade constantemente desafiou suas próprias bases morfológicas e mostrou-se, ademais, rica em formas e em procedimentos formais. $\mathrm{O}$ presente artigo tem por objetivo demonstrar o potencial construtivo de um procedimento composicional que denomino integração funcional, o qual consiste em imbuir contextualmente de funcionalidade acordes, fragmentos melódicos etc. concebidos por meios alienígenas à tonalidade funcional. Para tanto, exponho aqui os mínimos requisitos morfológicos para que as propriedades construtivas da tonalidade - como, e.g., as relações funcionais entre seções formais ou as relações de reciprocidade entre níveis locais e níveis mais amplos de organização harmônica - operem; e relato o processo de composição de uma peça para clarineta, na qual realizo um tal processo de integração funcional. Concluo, em especial, que esse procedimento propiciou uma relação constante de descoberta com a tonalidade e com a forma resultante, não prescrita e singular.

Palavras-chave: Composição musical; tonalidade funcional; forma musical; integração funcional.

\section{Abstract}

From Monteverdi to Mahler, R. Strauss and young Schoenberg, tonality has constantly challenged its very morphological bases and, moreover, it has proved to be rich in terms of forms and formal procedures. The main aim of this paper is to demonstrate the structuring potential of a compositional procedure I call functional integration, which consists in contextually imbuing functionality into chords, melodic excerpts etc. conceived by means other than functional tonality. For this purpose, I present the minimal morphological criteria for the structuring properties of tonality to work (e. g., the functional relations between sections of a work or the relations of reciprocity between local and larger scale levels of harmonic organization); and I report the compositional process of a clarinet piece, in which a process of functional integration is performed. In particular, I conclude that such a procedure has, above all, favored a constant attitude of discovery towards both tonality and the unique resulting form.

Keywords: Music composition; functional tonality; musical form; functional integration.

Compositor e professor adjunto do Departamento de Artes da Universidade Federal de Rondônia. Doutor em Artes (Processos de Criação Musical), pela USP e Mestre em Música (Processos Criativos), pela UNICAMP. Como compositor e como pesquisador, interessa-se pela interação entre a tonalidade funcional e práticas de composição dos séculos XX e XXI. 


\section{Introdução}

Há, no tratado de Harmonia de Schoenberg, uma passagem que, pessoalmente, considero muito preciosa por nela se concentrarem múltiplos interesses meus, seja como compositor, pesquisador ou professor de harmonia e contraponto. Trata-se de um trecho em que Schoenberg busca demonstrar composicionalmente como um dado acorde de oito notas (Fig. 1a), intensamente cromático (ainda que em uma distribuição predominantemente por sobreposição de terças e quartas), "quase poderia ocorrer em Bach"2 (Fig. 1b).

(a)

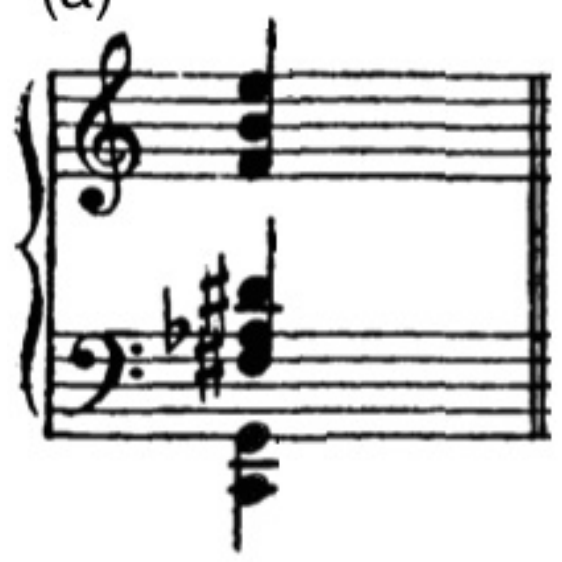

(b)

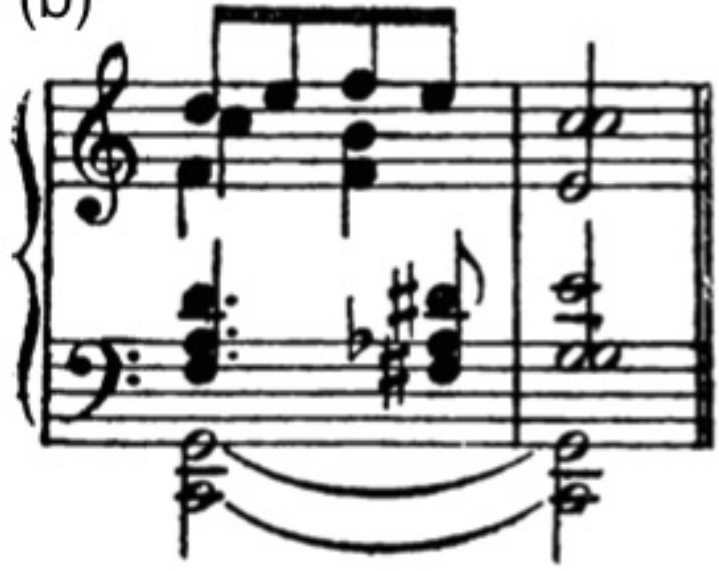

Fig. 1: Adaptada de Schoenberg (1922, p.443)

Para além da rica contribuição que essa passagem traz à discussão acerca da concepção schoenberguiana de emancipação e para além de prover aos alunos de harmonia exemplo de quão aberta morfologicamente pode ser a tonalidade, de quão imaginativamente eles podem usar seus recursos, há ainda ao menos três outros aspectos desse exemplo de Schoenberg que me interessam e sobre os quais amparo os primeiros passos deste texto.

Primeiramente, se por um lado é verdade que esse específico acorde de oito notas nunca ocorreu em Bach, por outro, tantos outros acordes bastante insólitos, os quais desafiam as históricas bases morfológicas (diatônica e triádica) da tonalidade - e os quais, deslocados de contexto, seriam possivelmente atribuídos a Schoenberg, Bartók (Fig. 2a) ou Stravinsky -, ocorreram, senão nele, em Mozart, Chopin, Grieg, Wolf, R. Strauss ou Monteverdi (Fig. 2b). Assim, se Stockhausen nos fez encontrar "maçãs na Lua", 3 também por vezes topamos com meteoritos no pomar - e tal como um meteorito que eventualmente encontrássemos em um pomar nos levaria a lembrar que o céu é aberto e que a Terra orbita no espaço, em meio a outros corpos, essas passagens insóli-

\footnotetext{
2 Schoenberg (2001 [1911/1922], p. 510-511, trad. M. Maluf; cf. 1922, p. 442-443).

3 Essa expressão foi usada algumas vezes por Stockhausen (ver, e.g., STOCKHAUSEN et al., 2004 [1995], p.382), em referência a peças suas - tais como o Gesang der Jünglinge (1955-1956), Kontakte (1958-1960), ou Hymnen (1966-1967) - em que sons familiares, como a voz juvenil no Gesang, ou as gravações de hinos em Hymnen, se tornam, em suas palavras, "completamente novos" (Ibidem) ao soarem em meio aos então inauditos - e como que de outro mundo - sons eletrônicos. Esclareço que, diferentemente de Stockhausen, ao falar aqui em "meteoritos no pomar", não me refiro aos próprios sons, mas às relações harmônicas.
} 
tas do repertório tonal parecem colocar a tonalidade em perspectiva, afirmar sua abertura e lembrar que há, ou haveria, outras maneiras de se conceber relações harmônicas.

(a)

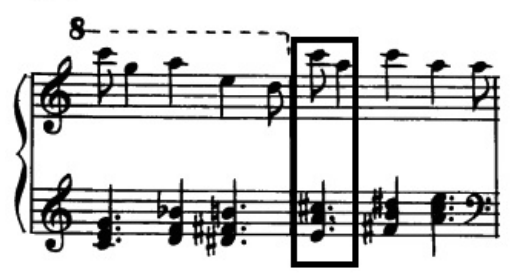

(b)

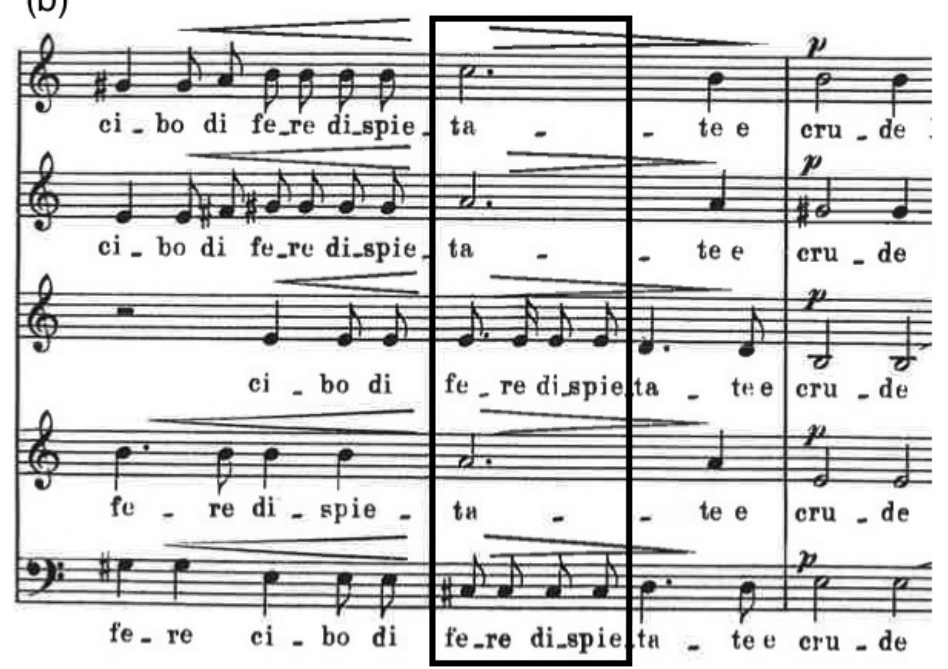

Fig. 2: (a) Bartók: Seis danças em ritmo búlgaro, nº 4 (ca. 1932-1939), c. 7-8;

(b) Monteverdi: "O Teseo" (1614), c. 49-51.

Um segundo aspecto interessante da demonstração de Schoenberg é que o acorde em questão ocorre agora no tempo, e as notas que o compõem parecem ganhar pesos e significados diferentes, na medida em que, agora, ao menos tão importante quanto sua constituição intervalar é o seu processo formativo. Ele já não se presta a ser visto ou concebido como um conjunto estático e qualitativamente homogêneo - algo como um "[0,1,2,3,4,5,8,9]" -, mas como fruto de diversas operações dinâmicas entrelaçadas: esta e aquela notas são baixos-pedal; outras três são frutos de cromatismo linear; aquela outra, ainda, a resolução de uma suspensão.

Ora, analisemos brevemente e sob essa perspectiva uma de nossas pedrinhas lunaires. O próprio primeiro acorde (Fig. 3a) de uma das primeiras obras ditas atonais de Schoenberg - o Op. 11, no 1 (1909) - não apenas poderia ter ocorrido em Chopin, como, de fato, quase ocorreu por duas vezes em 1846: na Barcarolle, Op. 60 (Fig. 3c), faltaIhe apenas o si, mas, com as devidas enarmonias, lá está o espaçado cluster formado por fá\#, mi\# e sol; e na Polonaise-Fantaisie, Op. 61 (Fig. 3b), por sua vez, o acorde de Schoenberg está completo, apenas acrescido de um ré. 
(a)

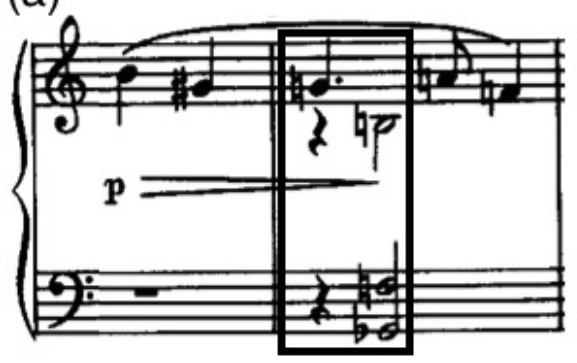

(b)

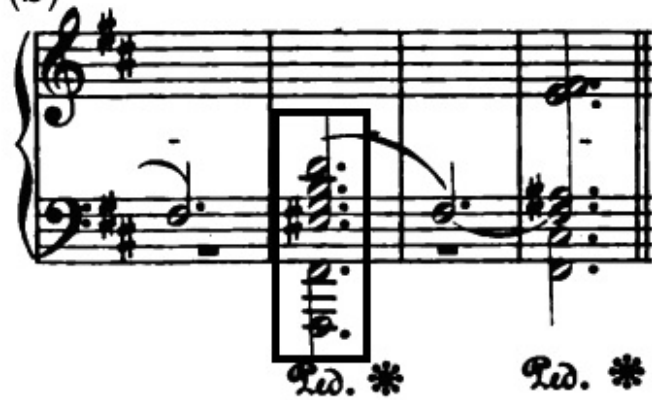

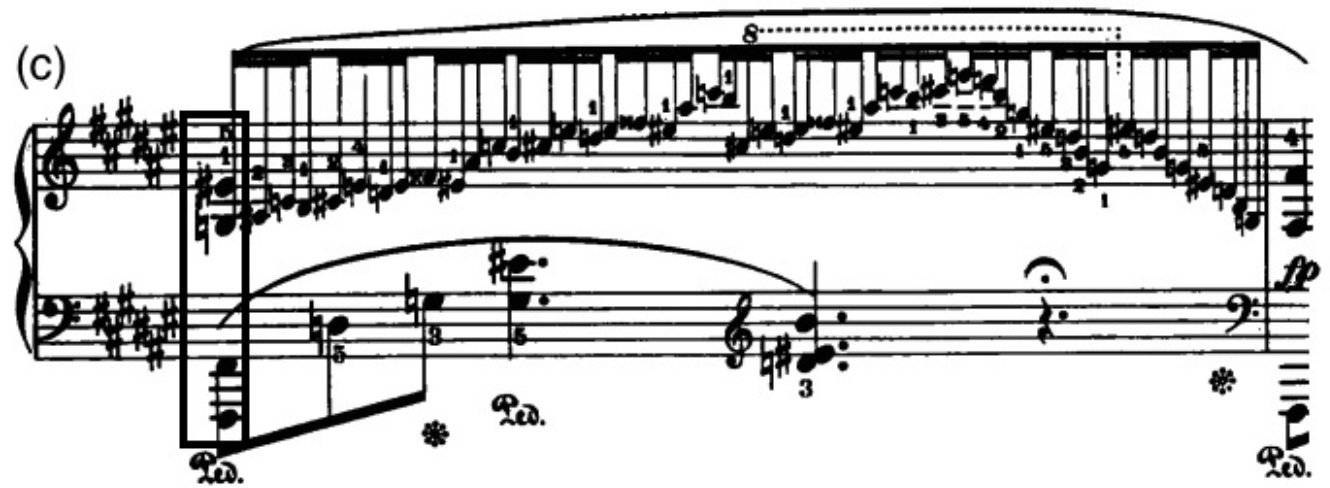

Fig. 3: (a) Schoenberg: Op. 11, nº 1, c. 1-2; (b) Chopin: Polonaise-Fantaisie, c. 144-147; (c) Chopin: Barcarolle, c. 110

Muito embora ambos os acordes sejam atacados em Chopin (e não apenas efemeramente formados em uma polifonia intrincada), os respectivos contextos evidenciam os significados das notas envolvidas e nos permitem acessar seus processos formativos: a resolução de ambos sobre fá\# se dá à maneira das resoluções dos acordes de sexta aumentada, de modo que mi\#, sol e si constituam virtualmente um dó\# dominante, com quinta rebaixada; e o fá\#, em ambos, trata-se mais simplesmente de um baixo-pedal - apesar das trocas de oitava na Polonaise.

Especialmente na Barcarolle, nosso meteorito parece ter caído com suficiente força para que se tenha aberto uma cratera ao seu redor, para que detritos se tenham espalhado pelo terreno e uma ou outra macieira tenha sido carbonizada. Localmente, o baixo-pedal que o constitui tem grande efeito, posto que atravessa, até sua ocorrência, sete compassos de crescente e intensa atividade harmônica e, por sua vez, a maneira - típica das resoluções de sexta aumentada - como o mi\# e o sol circundam cromaticamente o fá\# prolifera-se imediatamente em uma figuração vertiginosa, em que cada nota constituinte dessa espécie de dó\# dominante sideral é também cromaticamente circundada. Com o pedal de sustentação ademais acionado, faz-se soar, à sombra desse acorde, um denso cluster de nove notas. 


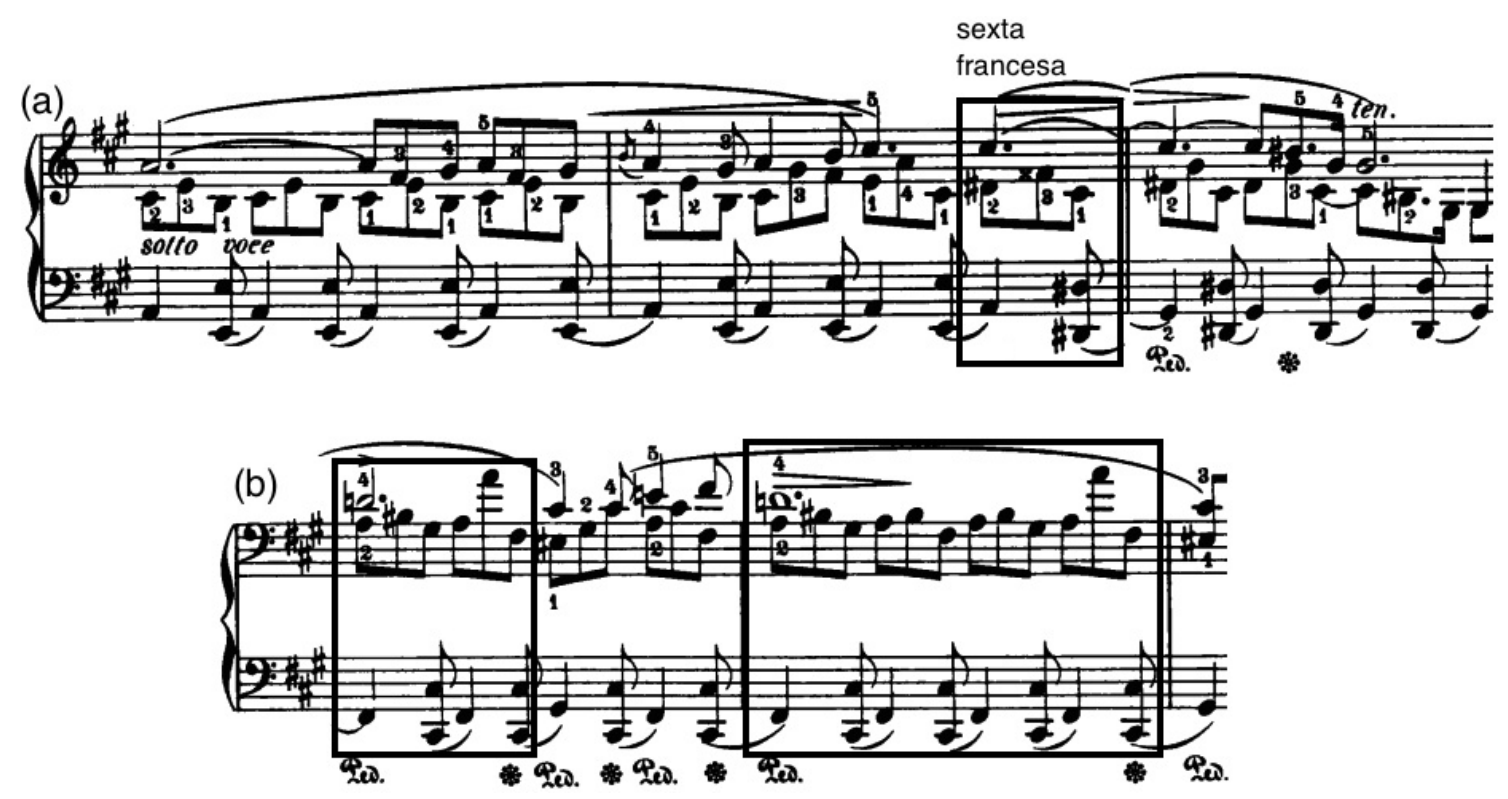

Fig. 4: (a) Chopin: Barcarolle, c. 40-42; (b) Chopin: Barcarolle, c. 48-49. Estão assinaladasas passagens em que se forma efemeramente uma verticalidade (com dó\#, si\# e ré) semelhante àquela atacada no c. 110.

De volta ao exemplo de Schoenberg, se aquele acorde de oito notas porventura ocorresse em alguma obra de Bach, podemos supor que seu entrelaçamento de baixos-pedal, cromatismos lineares e suspensões também não estaria isolado na peça, mas que, ao contrário, seu duplo baixo-pedal estaria sustentado já há alguns compassos e que a polifonia entre linhas cromáticas seria de algum modo tematizada na peça. Dificilmente saberíamos - assim como não o sabemos com certeza na Barcarolle de Chopin - se Bach teria premeditado aquele acorde e composto a peça a fim de alcançá-lo, ou se tal acorde teria sido uma descoberta em meio a um contexto propício. Em todo caso, a primeira via não só se mostra um jogo composicional possível, como também profícuo: mirar, no contexto da tonalidade, acordes ou passagens vindos de outro mundo implica descobrir como sintetizá-los com procedimentos que possam ser derivados da própria tonalidade e seu repertório - e tais procedimentos tendem não apenas a dispor esses acordes e passagens no tempo, como também, ao serem explorados alhures, a propiciar ainda outras descobertas. Da concepção primeira de um momento insólito, desenha-se o seu entorno, derivam-se pouco a pouco alguns traços da forma e ganham corpo, aqui e ali, outras passagens que não teriam sido, de outro modo, imaginadas. É esse potencial composicional o terceiro aspecto que me interessa naquele curioso excerto de Harmonia.

\section{Por uma tonalidade morfologicamente mais aberta}

Afora o receio do anacronismo, creio que um dos principais motivos pelos quais, de modo geral, relutamos em abordar a tonalidade em aulas de composição de nível superior seja o risco de que sua morfologia - não apenas acordal ou escalar, mas também rítmica, textural, formal, tímbrica etc. - castre ou sequestre a imaginação dos alunos e os impeça de experimentar as inúmeras abordagens à harmonia e à composição propiciadas 
ao longo do século XX - e propiciadas, aliás, justamente em decorrência do abandono da tonalidade funcional. Por outro lado, há de se reconhecer - e isto já era bastante claro para Schoenberg ${ }^{4}$ - que abdicar da tonalidade tende a implicar a abdicação também de algumas possibilidades próprias a esta de estruturação formal, em especial: a) as relações funcionais não apenas acordais e locais, mas também entre as próprias regiões tonais em que se deem as distintas seções formais de uma peça - e, portanto, também à distância e em maior escala, tal como tipicamente ocorre nas formas-sonata -; e b) as relações de reciprocidade entre níveis locais e níveis mais amplos de organização harmônica, em que um dado acorde, motivo ou nota, e.g., muda de função ao ser apresentado nesta ou naquela tonalidade $(\text { Tonart })^{5}$ e em que tal mudança de função se faz uma referência sensível para que, mesmo a distância e em maior escala, a modulação - ou, ao menos, a diferença entre as tonalidades envolvidas - seja experienciada.

A fim de conciliar uma imaginação harmônica experimental, nutrida pelo repertório e pelas práticas composicionais pós-1909, às possibilidades de estruturação formal propiciadas pela tonalidade, busquei, em tese de doutorado defendida em 2018,6 encontrar um minimum morfológico que permitisse ainda uma articulação de tais propriedades construtivas da tonalidade funcional. Antes, contudo, de expor os princípios aos quais cheguei na tese - e com os quais tenho trabalhado em meu próprio processo composicional -, um esclarecimento se faz necessário.

Ambas as propriedades construtivas da tonalidade (Tonalität) acima elencadas baseiam-se, evidentemente, nas relações de funcionalidade. Ao falar aqui em relações funcionais, contudo, deve ficar claro que não me limito ao sentido estrito dado por Riemann ao termo função (Funktion), em que este se atrela a três acordes principais de uma dada Tonart (tônica, dominante e subdominante), dos quais todos os outros acordes seriam representantes. Ora, essencialmente - e conforme a própria exposição de Riemann (1920 [1890], p.19; cf. 1893, p.60 e 155 ff.) -, a função trata-se do "significado" (Bedeutung) harmônico de um ente harmônico com relação a um dado centro tonal (i.e., a uma tônica, a uma Tonart, ou à tonalidade principal [Haupttonart] de uma peça), de modo que o termo parece comportar também um uso mais amplo, que não se limite nem ao nível dos acordes (mas se aplique também a notas ou Tonarten), nem a apenas três categorias. Assim, entendo por função: a maneira como um dado ente harmônico aponta para um centro tonal - ou para fora deste, rumando a outro - e, ao mesmo tempo, a qualidade sensível que esse ente harmônico assume em função de sua posição no interior da Tonart ou da Haupttonart. Ademais, entendo que, nessa acepção ampla, as funções possíveis são múltiplas e nuançadas, por vezes difusas, instáveis, ambíguas, menor etc.) quanto à tonalidade em seu sentido amplo (de sistema de organização harmônica) - , quando necessário, para fins de clareza, faço uso neste texto da terminologia alemã, que distingue Tonart (a tonalidade específica) de Tonalität (o sistema de organização harmônica). Esclareço ainda que, seguindo a convenção, uso maiúsculas para nomear as Tonarten (como, e.g., a tonalidade de Lá maior) e minúsculas para notas ou acordes (como, e.g., o acorde de lá maior).

6 "Tonalidade e seus desvios: reconhecimento e elaboração composicional de relações funcionais em meio a procedimentos harmônicos não funcionais", orientada pelo Prof. Dr. Silvio Ferraz de Mello Filho, no Programa de Pós-Graduação em Música da ECA-USP. 
de modo que, para melhor nomeá-las, recorro, de maneira heterodoxa, tanto à nomenclatura de Riemann como à de Schoenberg (2004 [1948]) e à nomenclatura por graus.

Feitas essas observações, seguem aqui os mínimos critérios morfológicos pelos quais entendo ser possível uma manutenção das relações funcionais (lato sensu) e, com estas, das propriedades construtivas da tonalidade.

1a) Escalas diatônicas, ou fragmentos escalares, podem representar uma Tonart. Isto não é novidade, e, de fato, o procedimento de se introduzir uma tonalidade por meio da apresentação de sua escala convencionalmente correspondente pode ser encontrado na própria Barcarolle de Chopin, na modulação rumo ao segundo tema: como se observa na Fig. 5, abaixo, logo após repetidas cadências sobre a tônica, fá\# maior, são apresentadas sua homônima (fá\# menor, c. 35) e, com esta, a base diatônica de sua tonalidade paralela, ${ }^{7}$ Lá maior (c. 35-38). Há de se notar que esta nova Tonart, na qual se apresenta o segundo tema (a partir do c. 39), é estabelecida sem que haja, para isso, uma cadência.
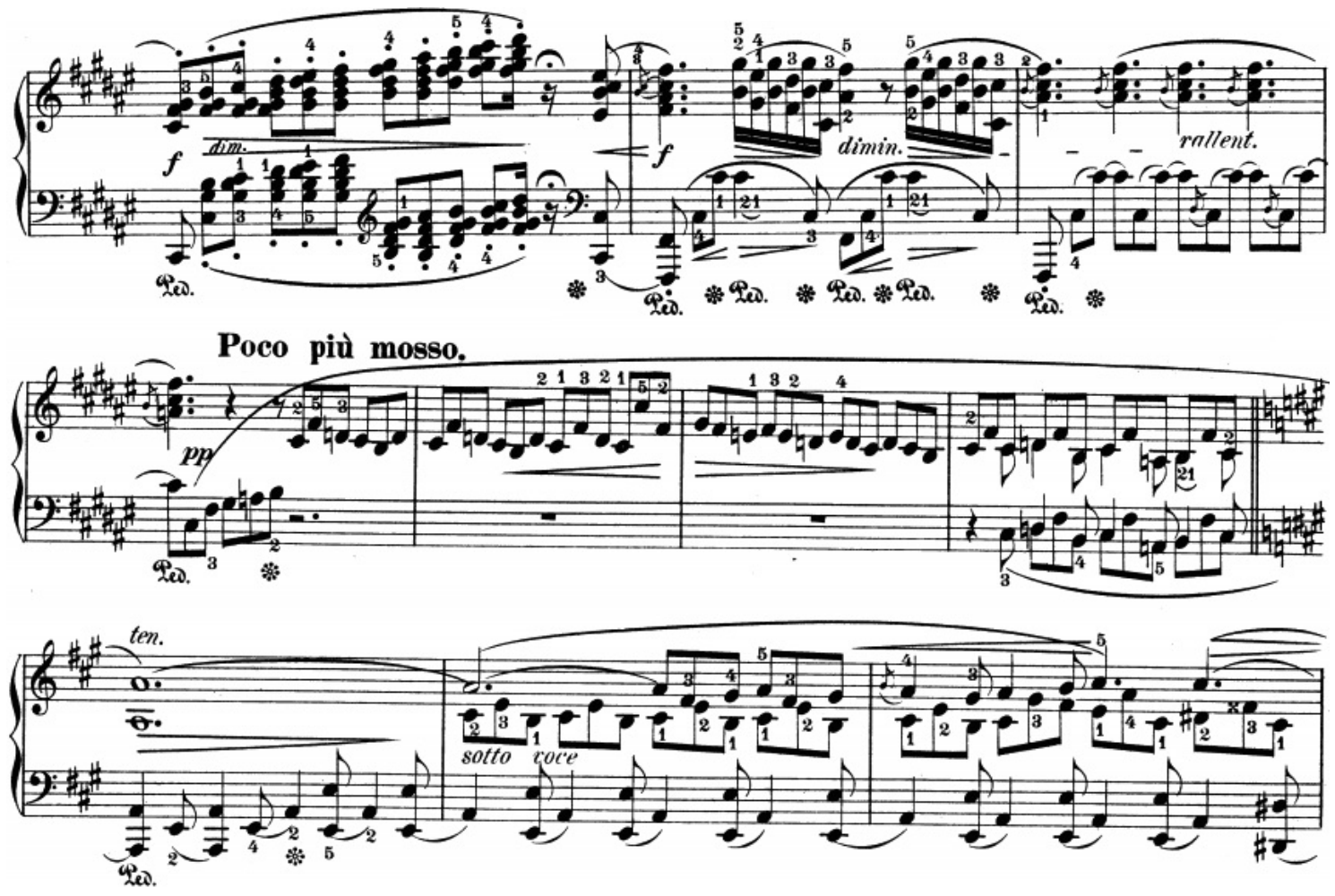

Fig. 5: Chopin: Barcarolle, c. 32-41.

1b) Conforme o princípio schoenberguiano da monotonalidade ${ }^{8}$ e tal como se verifica abundantemente e com especial clareza no estilo sonata, relações funcionais não se estabelecem apenas entre acordes, mas também entre Tonarten. Assim, 1) para que se estabeleçam relações funcionais, faz-se necessária uma base diatônica, mas não uma base triádica. 
2a) Uma Tonart de base triádica pode ser expressa sem que sequer ocorra sua tríade de tônica, mas por uma espécie de convergência funcional, em torno desta, das várias outras estruturas acordais (enunciadas ou implícitas). Se justapusermos, e.g., um acorde de sol maior a outro de fá maior, tenderemos a interpretá-los como expressando uma tonalidade de Dó maior, seja porque, juntos, sol maior e fá maior contêm a base diatônica quase inteira de Dó maior (o que remete ao princípio anterior), seja porque a relação funcional mais simples que possa haver entre esses dois acordes se dá precisamente nessa Tonart - e é nesse sentido que, juntos, eles tendem a convergir em torno de Dó. Algo semelhante se dá nos compassos iniciais do prelúdio de Tristão e Isolda (1857-1859). Aqui, a forte sugestão de Lá menor, mesmo na completa ausência de sua tríade de tônica, se dá em boa medida pela ocorrência de sua dominante nos compassos 3 e 16 (ver Fig. 6, abaixo), aludindo-se - ainda que sem realizar - à habitual cadência; mas tal sugestão de Lá menor também se deve ao fato de que as dominantes em que se encerram as demais frases, nos compassos 7, 11 e 13, não apontam para quaisquer outros acordes, mas precisamente para acordes próximos, primários, de Lá menor: respectivamente, sua paralela (dó maior) e sua dominante (mi maior).
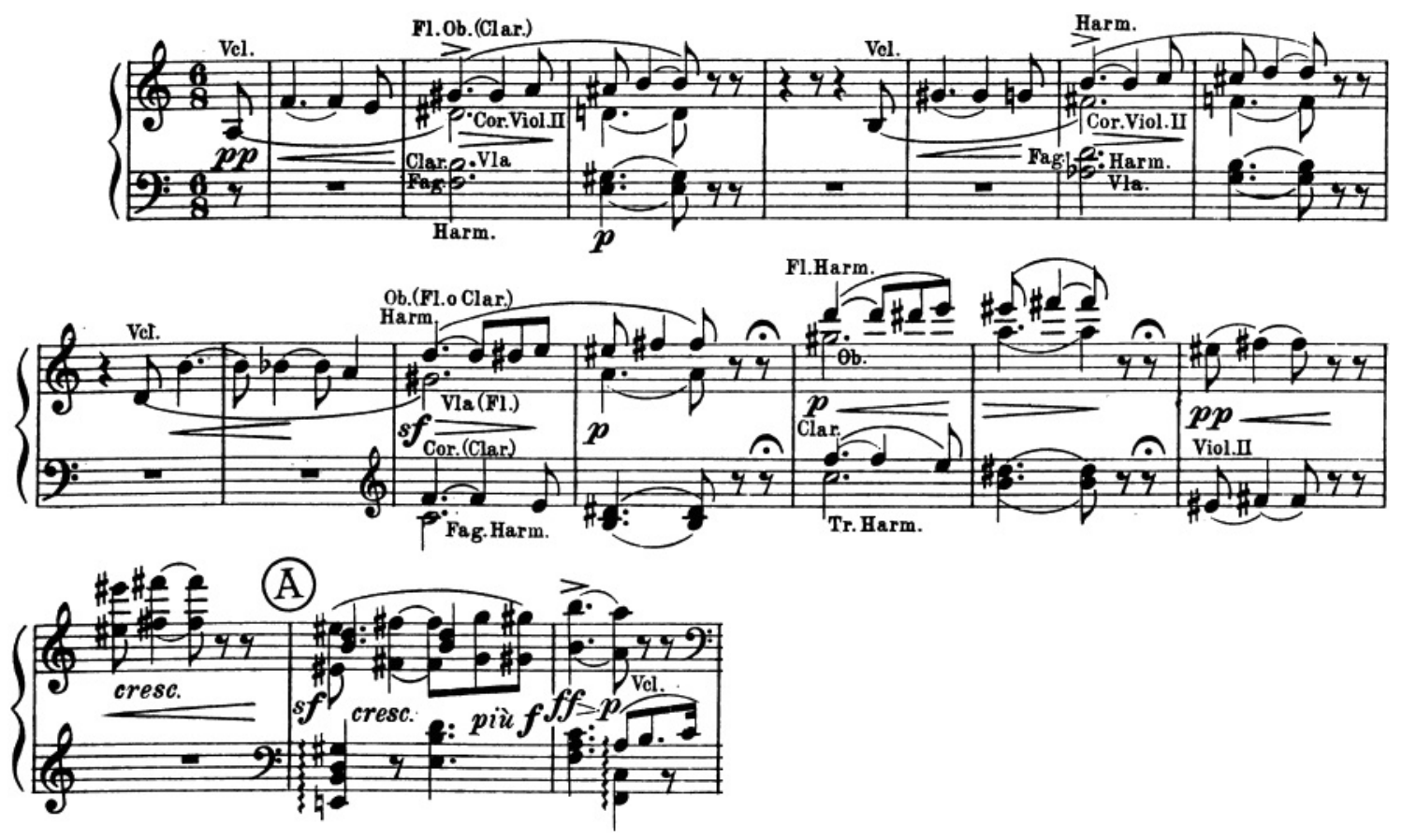

Fig. 6: Wagner: Tristão e Isolda, prelúdio, c. 1-17 (redução).

2b) Analogamente, também uma tonalidade principal (Haupttonart) há de poder ser desenhada pela convergência, em torno de si, de outras tonalidades. Na Sonata Waldstein (1804), de Beethoven, e.g., embora a tríade tônica de dó maior seja ostensivamente reiterada já nos dois primeiros compassos da peça, ela é enunciada no contexto de uma progressão cadencial rumo a sol maior (c. 3), de modo que, antes de a Haupttonart de Dó maior ser diretamente expressa, são apresentadas as regiões de sua dominante (c. 1-4), de sua subdominante (c. 5-7) e de sua homônima (c. 9-13) - e mesmo que a tríade de dó maior dos compassos 14 e 15 soe já inequivocamente como 
uma tônica (diferentemente do que ocorre nos compassos iniciais), ela é novamente absorvida por uma progressão cadencial rumo à sua dominante (c. 15-16). (De fato, a primeira vez na peça em que há uma cadência, propriamente, sobre dó maior e em que se apresenta integralmente, em uma única frase, a base diatônica de sua Tonart é já no final da exposição, nos compassos 84 e 85.)

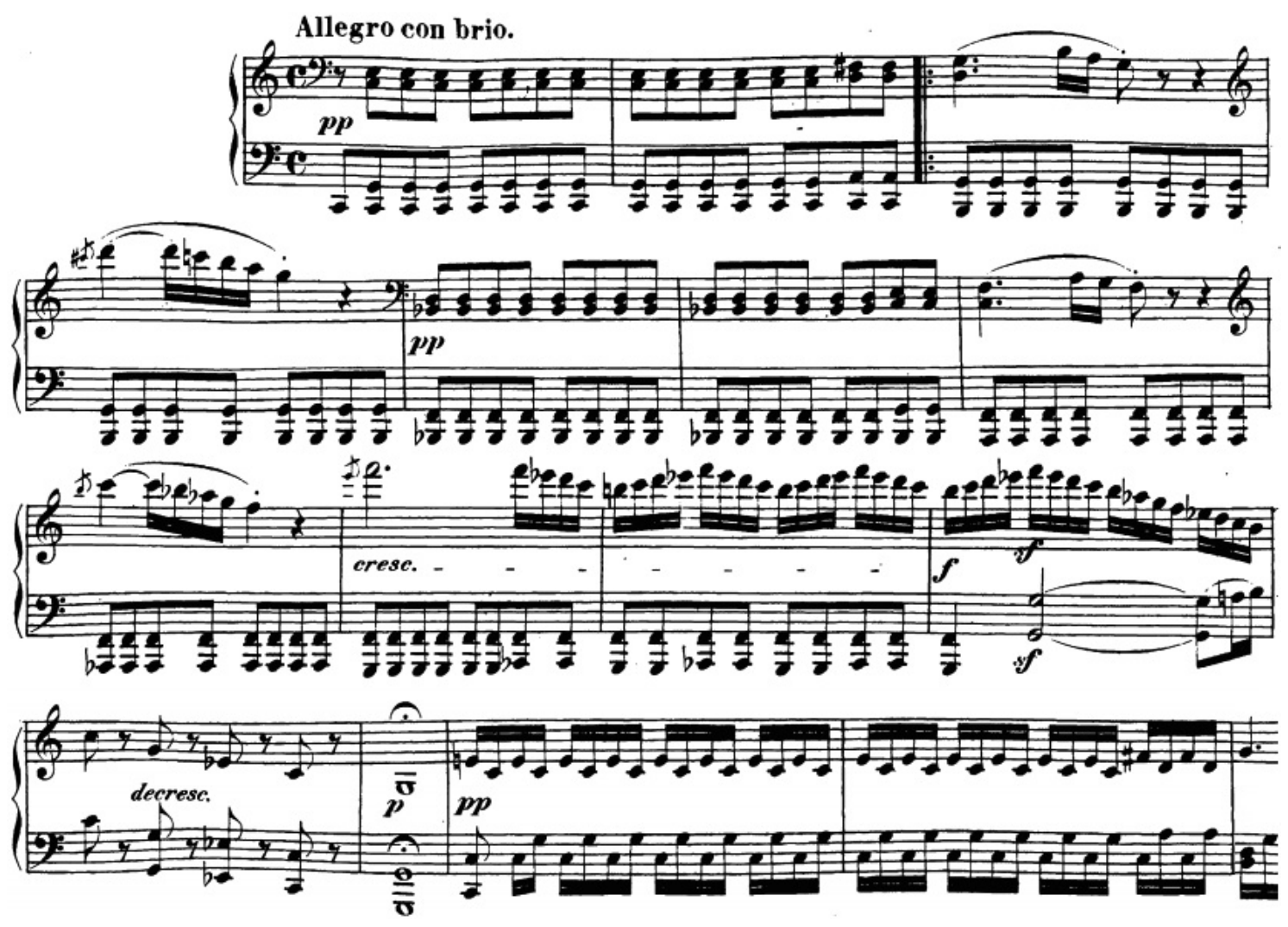

Fig. 7: Beethoven: Sonata Waldstein, Op. 53, c. 1-16.

É evidente que uma Tonart estabelecida exclusivamente por esse recurso - o que, graças à ênfase sobre a tríade de dó maior, não chega a ser o caso desse início da Waldstein - será mais vaga do que uma tonalidade diretamente expressa, e, ademais, que, quanto mais dilatado temporalmente ou esparso for um tal processo, menos eficaz será ele em termos perceptivos. Há de se notar, contudo, que, em repertório, a convergência de outras regiões tonais sobre uma Haupttonart é um recurso bastante comum, se não para apresentar uma tonalidade ausente, para reforçar uma tonalidade estabelecida, ou por estabelecer: no Prelúdio em Dó maior, BWV 846 (1722), e.g., o restabelecimento de Dó maior após uma quase modulação à região de sua dominante, nos c. 5-11, não se dá diretamente por uma cadência sobre a tônica, em que esta poderia soar como a subdominante de um Sol tonicizado, mas, de maneira provavelmente mais eficaz, o retorno à tônica é antecedido por uma cadência sobre sua subdominante paralela, ré menor (ver Fig. 8, abaixo) - abundam em Bach, aliás, exemplos semelhantes -; em formas-sonata, por sua vez, Rosen (1980, p.284 ff.) demonstra como incursões, na recapitulação, à região da subdominante e de outras tonalidades "mais bemóis" (ver quarto princípio, pouco adiante) são um recurso recorrente para compensar, em larga 
escala, a modulação na exposição à dominante - para reduzir o senso de tonicidade que essa região assumira, para, ao contrário, convergir sobre a tonalidade principal e para reforçar, assim, um senso formal de resolução.
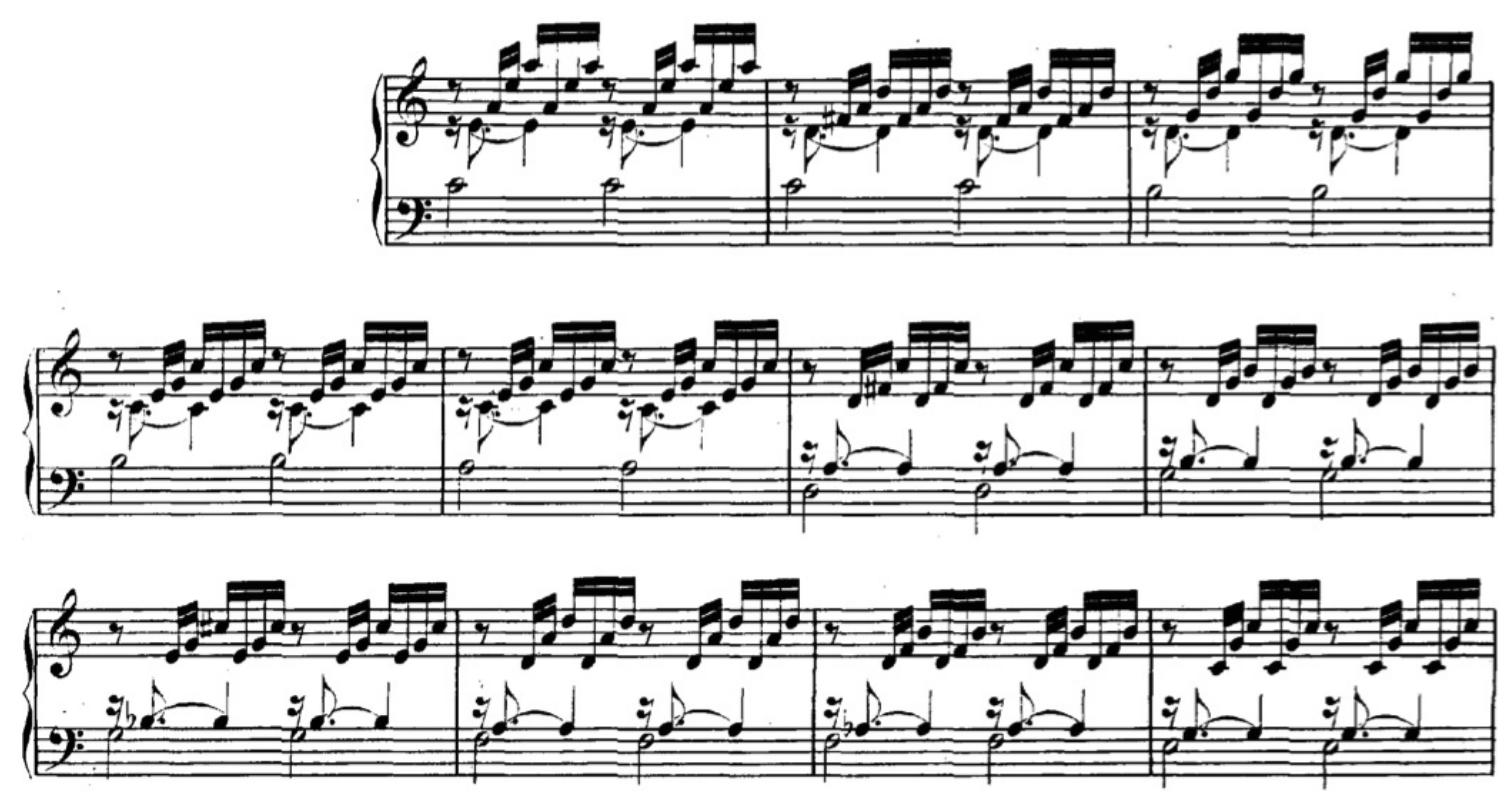

Fig. 8: Bach: BWV 846, c. 5-15.

3) Mesmo a base diatônica de uma dada Tonart é em boa medida flexível - o que, ainda em repertório tonal, se verifica, por exemplo, na virtual fusão de homônimas em compositores como Wagner, Wolf ou R. Strauss - e comporta, ademais, aproximações cromáticas a cada um de seus graus. A fim de abarcar as diversas alterações possíveis nos distintos graus de uma dada base diatônica, propus na tese e trabalho composicionalmente com uma concepção estendida de diatonismo, ${ }^{9}$ pela qual entendo ser uma escala diatônica: a) qualquer subconjunto escalar do total cromático que seccione a oitava em sete graus, respectivamente representados pelos sete nomes de notas (dó, ré, mi etc.), individualmente naturais, bemóis, sustenidas etc.; b) em que tais sete graus, se dispostos no ciclo de quintas, não completem ou ultrapassem um ciclo completo.

Assim, aquele segundo compasso do Op. 11, no 1 (Fig. 3a, acima), e.g., não estaria circunscrito, com sua grafia original, em uma base diatônica, por portar em si tanto sol como sol bemol (Fig. 9a, abaixo); mas basta adotar uma grafia mais próxima à de Chopin (i.e., com fá\# e mi\#) para que o possamos compreender como correspondente a um segmento escalar diatônico em nossa concepção estendida de diatonismo (Fig. 9b) - note-se, ademais, que esse conjunto está abarcado em um único ciclo de quintas (Fig. 9c).

9 Uma exposição mais detalhada e abrangente de tal concepção de diatonismo encontra-se em Oliveira (2018, p.134-145), em capítulo acerca da "representação de centralidades locais por diatonismo" (p.128ff.). 
(a)

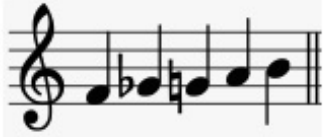

(b)

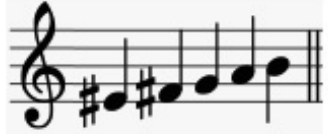

(c)

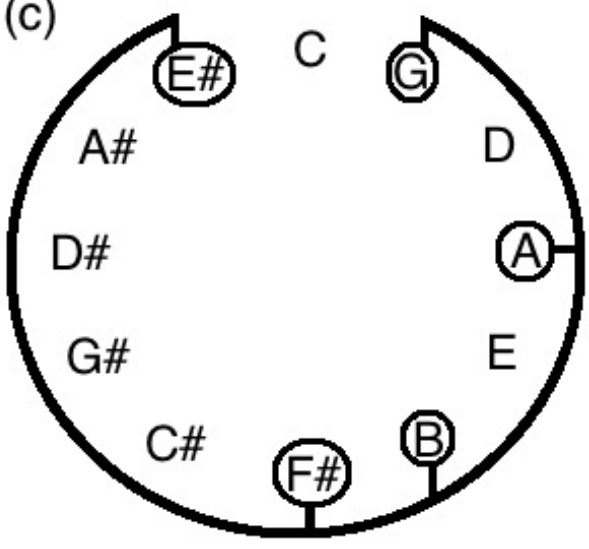

Fig. 9: (a) Representação escalar das notas constituintes do c. 1 do Op. 11, n 1 de Schoenberg;

(b) representação escalar enarmonizada das mesmas notas; (c) representação destas no ciclo de quintas.

O denso acorde formado no c. 142 da Sinfonia no 9 (1909) de Mahler (Fig. 10a), por sua vez, não se circunscreve plenamente em uma base diatônica, seja por ter dois sóis (natural e sustenido), seja porque, em uma grafia alternativa, com fá dobrado sustenido em vez de sol natural (Fig. 10b), ele extrapolaria o ciclo de quintas (Fig. 10c).

(a)

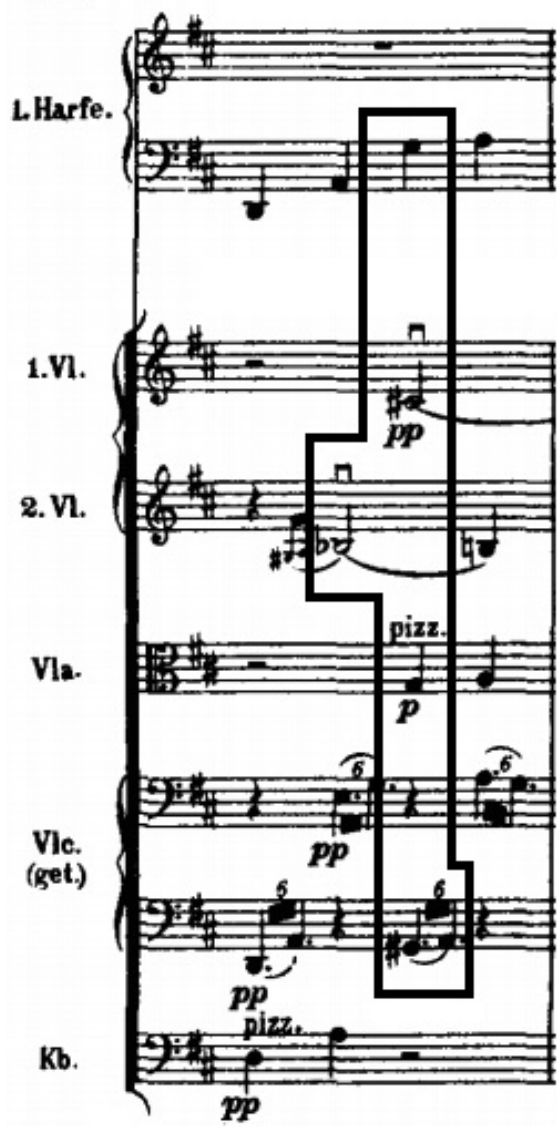

(b)

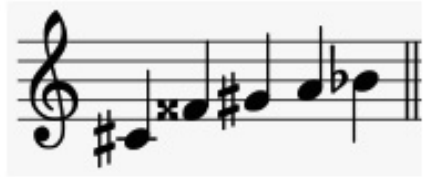

(c)

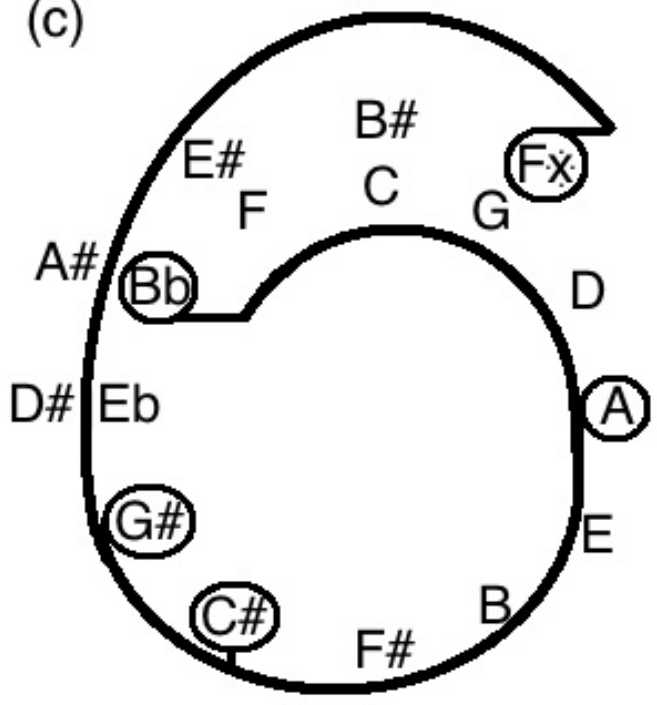

Fig. 10: (a) Mahler: Sinfonia n 9, Mov. I, c. 142; (b) representação escalar do mesmo acorde, enarmonizado; (c) representação do mesmo acorde, enarmonizado, no ciclo de quintas. 
Ainda assim, faz-se possível reportar tal acorde a uma base diatônica se considerarmos que o sol\# não pertence a esta, mas ocorre, na peça, como aproximação cromática ao lá, este, sim, pertencente (Fig. 11).

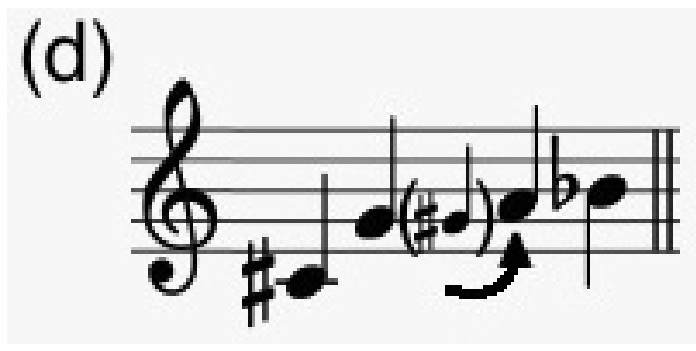

Fig. 11: Representação escalar do acorde do c. 142 do Mov. I da Sinfonia nº 9 de Mahler. O sol\#, entre parênteses, é entendido como uma aproximação cromática de lá.

Pode-se objetar que nem sempre as supostas bases diatônicas vigentes a cada momento de uma obra são integralmente expressas; que bases diatônicas tão distantes dos convencionais modos maior e menor já não representam tão claramente quanto estes alguma dada Tonart e; ainda, que em passagens mais densamente cromáticas pode tornar-se arbitrária a distinção entre quais notas pertenceriam a um suposto diatonismo de base e quais seriam aproximações cromáticas. Aqui entra nosso quarto princípio: 4) entendo que haja tipos de relações funcionais mais difusos - fuzzy -, que possam operar mesmo entre acordes, passagens ou seções formais ambíguas quanto às suas centralidades. Assim - e mais uma vez a exemplo do que se observa no estilo sonata -, podemos considerar: 4a) que conjuntos de notas mais sustenidas com relação a uma referência tonal (i.e., situadas à sua destra no ciclo de quintas) sejam, com relação a esta, difusamente dominantes; que, inversamente, conjuntos mais bemóis (i.e., situados à sinistra) lhe sejam difusamente subdominantes; e 4b) que passagens mais instáveis ou mais ambíguas sejam também formalmente (mas não necessariamente intervalarmente) mais dissonantes. ${ }^{10}$

\section{Relato composicional}

Ao iniciar, em 2014, a pesquisa acima mencionada, eu estava, havia cerca de dois anos, basicamente interessado em encontrar na tonalidade meios de dar maior coesão formal às minhas peças. Eu vinha trabalhando com processos composicionais de cunho pós-serial - em boa medida baseados nos grids de Ferneyhough ${ }^{11}$-, e a tonalidade, ainda que esta se tornasse, a cada peça, mais absorvida no processo, tinha, ainda assim, um caráter auxiliar: mais ou menos à maneira dos fixadores ortopédicos - aqueles "pinos", usados em fraturas severas ou complexas -, ela era então exterior e rija e vinha, extrinsecamente, garantir correspondências molares e um senso global de unidade.

\footnotetext{
10 Para exemplificação de ambos esses tipos de relação (4a e 4b) em formas-sonata dos séculos XVIII e XIX, ver os capítulos sobre desenvolvimento (p.262 ff.) e recapitulação (pp.284 ff.) de Sonata Forms (1980), de C. Rosen.

11 A respeito dos grids, ver sobretudo o texto de Ferneyhough sobre seu Segundo Quarteto de Cordas (1980), nos Collected Writings (1995 [1982], pp.117-30).
} 
Já em meio à pesquisa, contudo, dei-me conta de algo que me permitiu inverter a abordagem: que, para além daquelas propriedades construtivas da tonalidade que se amparam de maneira suficiente nas relações de funcionalidade (a unidade sob a égide da tônica, a articulação formal por meio da modulação, a relação funcional entre seções formais e a reciprocidade entre níveis locais e níveis mais amplos de organização harmônica), haveria ao menos um tipo de possibilidade de estruturação formal que, sendo-lhe peculiar, dependeria, precisamente, de sua interação com outras lógicas harmônicas. Trata-se do objeto deste texto, do impacto dos meteoritos no pomar, daquilo que tenho chamado de integração funcional, i.e.: o processo pelo qual um acorde, fragmento melódico, estrato polifônico etc. concebido por meios alienígenas à tonalidade (Tonalität) (como, e.g., o cromatismo linear, técnicas de cunho serial ou pós-serial, jogos motores/gestuais, jogos de harmonia-timbre etc.) é imbuído de funcionalidade no contexto de uma peça. Agora já não se tratava de impor uma tonalidade pronta e uma forma exterior a uma ideia composicional; já não se tratava de colonizar a Lua, mas, ao contrário, de descobrir uma forma a partir de um evento imprevisto e insólito, de descobrir, graças a uma alteridade harmônica, uma tonalidade singular - o que afinal é uma macieira se sua reprodução depende de insetos polinizadores, se seu longo trajeto evolutivo de alguma maneira se entrecruzou com o das abelhas, e se o céu, já não mais abobadado, se estende dos espacinhos entre suas folhas até as galáxias mais distantes?

No trecho que se segue, relato o processo de escrita de uma peça minha finalizada em abril de 2020: trata-se da segunda de três peças curtas para clarineta solicitadas a mim pelo compositor e professor de clarineta da UFMS, Max Packer, e destinadas, cada uma, ao estudo de algum aspecto específico da técnica convencional do instrumento. $\mathrm{Na}$ primeira dessas peças, conforme seu pedido, deveriam abundar trinados e trilos; na segunda, aqui em questão, a figuração deveria ser em boa medida pendular, a fim de trabalhar uma homogeneidade da qualidade sonora em meio a saltos e trocas de registro; e na terceira,12 finalmente, eu deveria trabalhar com apojaturas e staccatos. Além disso, de minha parte, decidi que em cada uma das peças haveria ao menos um momento em que, à maneira de uma série dodecafônica (mas sem que se lhe desse o tratamento de uma série), o total cromático seria apresentado de maneira condensada. A primeira peça, por exemplo (e como se vê na Fig. 12, abaixo), encerrava-se com a justaposição dos pares de notas constituintes de todos os seis trilos nela empregados (dó\#4-ré4; dó4-fá4; lá3-sol3; mi3-ré\#4; lá\#3-si3; e fá\#4-sol\#4 ${ }^{13}$, além das digitações correspondentes no registro Clarion), os quais completavam os doze tons.

\footnotetext{
12 Finalizada em junho de 2020, posteriormente à redação deste artigo.

13 Considero dó4 o dó central. Também, para melhor correspondência entre texto e partitura, refiro-me aqui e em todo o relato que se segue às notas tal como escritas.
} 


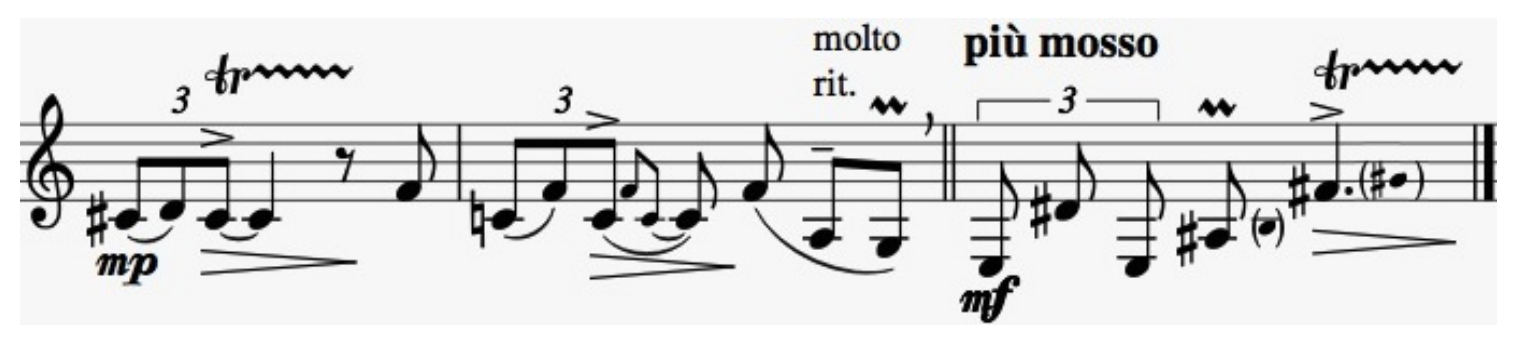

Fig. 12: Compassos finais da peça I.

Com essas orientações preliminares, adotei dois pontos de partida para essa segunda peça. Primeiramente, em resposta à demanda por se trabalhar a homogeneidade sonora em meio a saltos e passagens de registro, decidi que, afora os movimentos pendulares, seria de alguma maneira tematizada na peça a passagem entre duas notas intervalarmente próximas, mas radicalmente distintas quanto às suas colunas de ar: o sol4, no primeiro registro e com todas as chaves abertas; e o si4, no segundo registro e com todas as chaves fechadas.

Em segundo lugar, em resposta à ideia de apresentar condensadamente o total cromático ao menos uma vez na peça; e tendo em vista que uma das maneiras que eu teria para atribuir relevância ao motivo sol-si seria fazê-lo ocorrer no interior de algumas tonalidades distintas, rearmonizando-o a cada vez; decidi que esse fragmento protododecafônico do qual eu partiria seria constituído por uma modulação entre duas tonalidades que fossem relativamente distantes entre si, mas que comportassem, ambas, as duas notas desse motivo - e esbocei, assim, a seguinte sequência melódica, como que modulando, por troca da base diatônica, de Mi menor a Dó menor:

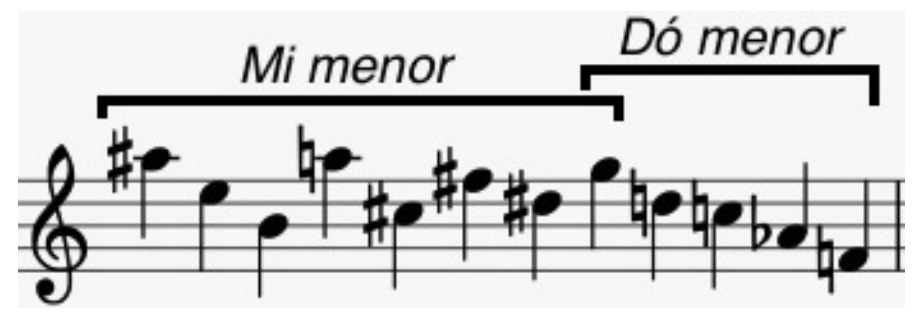

Fig. 13: Ponto de partida do processo composicional: apresentação condensada do total cromático.

A fim de tornar mais claro seu caráter modulatório e de experimentar com seu fraseado interno, quase imediatamente dispus no tempo tal fragmento, atribuindo-lhe definição rítmica e puxando fios para ambos os lados, ao esboçar um grande arpejo de mi menor que os antecederia e ao seguir dessa sequência protododecafônica até o fim da frase, com uma apresentação do sol-si - aqui com o aspecto de uma dominante de dó menor.

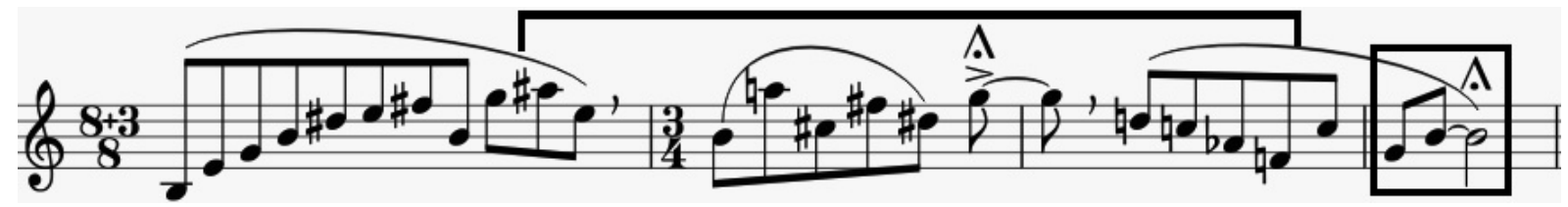

Fig. 14: Primeiro fragmento escrito, correspondente aos c. 12-15 da peça. Estão assinalados: a apresentação condensada do total cromático e; uma ocorrência do motivo sol-si. 
Com essa passagem esboçada, havia já bastante a ser trabalhado. Estavam dadas aqui duas tonalidades não próximas, cuja relação entre si, nada óbvia do ponto de vista de uma funcionalidade estrita, deveria ser trabalhada ao longo da peça. Para que essa modulação de Mi menor para Dó menor, aliás, não soasse disparatada, Dó menor deveria provavelmente ser apresentada antes de se chegar a essa passagem - e isto já dizia respeito, ainda que vagamente, à forma. É também notável que, no interior do segmento protododecafônico dessa passagem, ambas as Tonarten, Mi menor e Dó menor, estão como que ocas: há alusões à dominante da dominante (com lá\#-mi) e à própria dominante de $\mathrm{Mi}$, bem como à subdominante de Dó menor, mas não às suas respectivas tríades de tônica. Quanto a esse procedimento protododecafônico, de se apresentar o total cromático de maneira condensada, haveria versões mais diluídas dele, para que ele de alguma maneira participasse da peça já antes e para que essa passagem fosse, também nesse sentido, resultado de uma construção? Ritmicamente, por sua vez, parecia já um jogo profícuo manter predominantemente na peça um fluxo de colcheias, do qual se destacariam irregularidades - como o adendo ternário ao primeiro compasso dessa passagem ou a síncope protagonizada pelo sol agudo - e o qual, conjugado ao perfil pendular, tenderia a produzir - tal como no segundo compasso desse fragmento - uma polifonia latente.

Tendo por alvo essa passagem e extraindo dela seus componentes figurais, procedi ao início da peça. Primeiramente, como a peça anterior terminava em um trinado entre fá\# e sol\# e em uma alusão a Si maior (ver Fig. 12, pouco acima), pareceu-me propício começar esta segunda diretamente com o motivo sol-si e, assim, enriquecê-lo, de partida, com uma carga harmônica da primeira peça. Decidi também que, se esse início seria, de fato, em torno de Dó menor, uma maneira de valorizar, enquanto procedimento, a apresentação do total cromático sem que isso se desse de maneira já tão condensada seria apresentar todas as outras onze notas antes do próprio dó (a ordem de apresentação do total cromático está assinalada abaixo, na Fig. 15). Para conseguir isso já formando um senso de centralidade de Dó menor, recorri não apenas a uma ou outra aproximação cromática, mas, sobretudo, vali-me do recurso, já mencionado, de fazer convergir em torno de uma tonalidade principal as bases diatônicas de regiões tonais que se lhe avizinhassem: neste caso, aquelas de Sol menor (seu $V$ grau, um pouco mais sustenido) e de Fá menor (sua subdominante, um pouco mais bemol). Ademais, cuidei, evidentemente, de estabelecer, já no início, a figuração pendular, primeiro em torno de sol4, depois em torno de ré4.

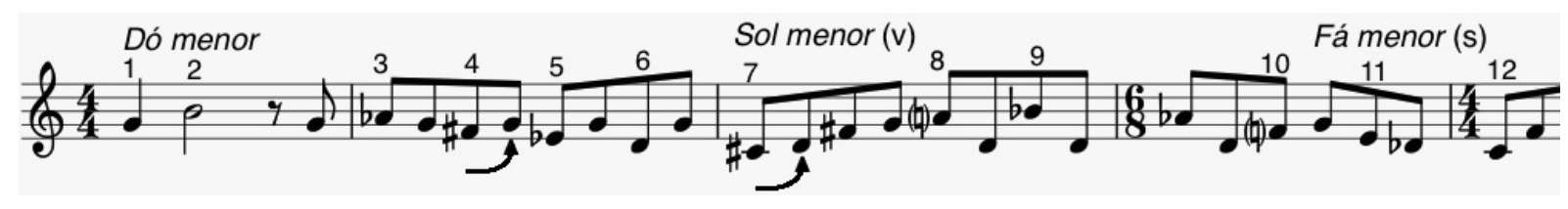

Fig. 15: Esboço dos compassos iniciais, com indicação da primeira ocorrência de cada uma das doze notas e com as aproximações cromáticas assinaladas por setas.

Na sequência, essa breve incursão em Fá menor propiciou um insight: bastaria avançar um pouco mais na direção dos bemóis, até a região de Lá bemol menor, e ha- 
veria ocasião para uma harmonização inusitada do motivo principal, em que, entre a sensível de lá bemol e sua terça menor, ele estaria agora em uma versão enarmônica: sol-dó bemol - e, valendo-me da síncope, mesmo seus valores rítmicos viriam a ser semelhantes aos iniciais (de semínimas), mas metricamente deslocados. Para não perder a centralidade de Dó menor de vista, cuidei de retornar quase imediatamente à região de sua paralela, Mi bemol, cuja base diatônica é, evidentemente, muito próxima à do próprio Dó menor.

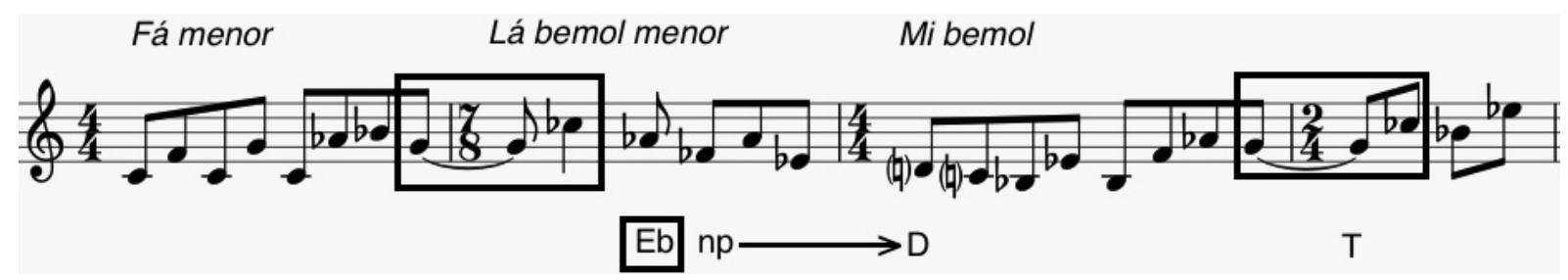

Fig. 16: Esboço dos c. 5-8, com as versões enarmonizadas do motivo sol-si assinaladas e com indicação das Tonarten sugeridas a cada momento.

Em boa medida, o procedimento desse início foi retomado de maneira invertida e simétrica na sequência daquele fragmento do qual partíramos. Se a peça fora iniciada com o motivo sol-si em Dó menor; se Dó menor fora delineada de maneira sobretudo indireta, por meio da convergência de regiões vizinhas sobre tal Tonart, e apresentando-se as outras onze notas antes do próprio dó; e se a peça progrediu primeiro não à região da mediante Mi menor, mais sustenida, mas, contrária e simetricamente, à região mais bemol da submediante Lá bemol menor - na qual fiz o motivo principal ressurgir na forma sol-dó bemol -; agora, partindo novamente de sol-si: a) delineei a tonalidade de Mi menor por meio das regiões próximas de Lá menor (subdominante) e Si menor (V grau); b) apresentei todas as outras onze notas antes de apresentar o próprio mi (ver Fig. 17, abaixo); c) fiz o movimento harmônico progredir não imediatamente de volta à submediante Dó menor, mais bemol, mas, ao contrário, à mediante Sol\# menor, mais sustenida; e d) fiz com que, em Sol\# menor, ressurgisse o motivo principal, agora enarmonizado enquanto fá dobrado sustenido-si. Também semelhantemente ao que ocorrera no primeiro trecho da peça, cuidei de que, após a incursão na região de Sol\# menor, se retornasse imediatamente a Mi menor, a fim de não perder sua centralidade de vista.

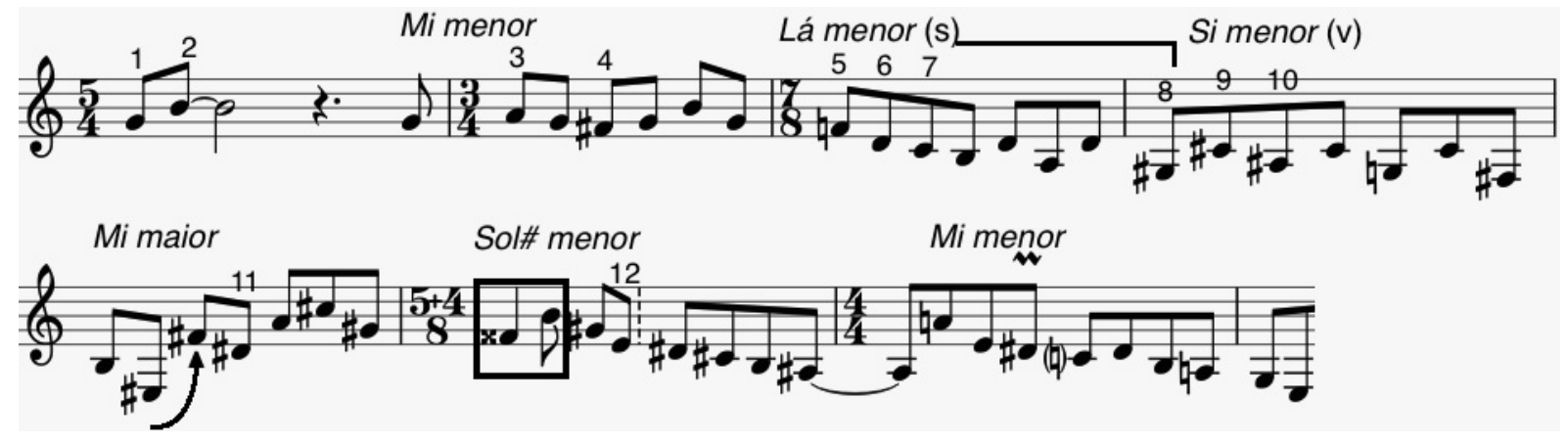

Fig. 17: Esboço dos c. 15-21, com indicação da primeira ocorrência de cada uma das doze notas. No c. 19, a seta assinala uma espécie de aproximação cromática entre mi\#3 e fá\# 4 . 
Essas visitas a Lá bemol menor (ver Fig. 16, pouco acima), a partir de Dó menor, e a Sol\# menor, a partir de Mi menor, cumprem aqui um duplo propósito. Por um lado, como já colocado, cada uma dessas tonalidades abriu espaço para que ocorresse diferentemente (e por vezes enarmonizado) o motivo sol-si e para que este, num jogo de reciprocidade, se enriquecesse a cada vez com novos sentidos harmônicos; revelasse entre tais tonalidades - inclusive entre Dó e Mi menor - um elo, algo em comum; e oferecesse à sensibilidade, através das sucessivas mudanças em seu caráter harmônico, uma referência para que se experienciassem, a distância, os efeitos das modulações, as diferenças entre as tonalidades visitadas ao longo da peça (sugiro ao leitor comparar, por exemplo, os efeitos desse motivo nos c. 1-3, Fig. 15, e nos c. 15-17, Fig. 17). Por outro lado, essas tonalidades, mediantes e submediantes, umas das outras, triangulam de modo a revelar relações funcionais possíveis entre Dó menor e Mi menor. Ora, se em nosso meteorito, nos compassos 13 a 14 (ver Fig. 14, pouco acima), a modulação de Mi a Dó menor se dava pela simples troca de base diatônica, mas não por uma relação funcional clara, estas outras duas relações de mediantes estão estabelecidas na peça através de percursos mais propriamente funcionais, em sentido estrito: chega-se a Lá bemol como uma paralela menor de Fá menor (por sua vez subdominante de Dó) e deixa-se Lá bemol como uma subdominante menor de Mi bemol (paralela de Dó); e Sol\# menor, por sua vez, ao ser antecipada e sucedida por menções à dominante de Mi, é introduzida e abandonada enquanto uma paralela de sua dominante. Desenham-se assim na peça relações de mediantes e submediantes - tais como o são Mi e Dó menor entre si - em que ora a mediante de uma dada tonalidade se apresenta como uma paralela de sua dominante, ora a submediante de uma dada tonalidade se apresenta como paralela menor de sua subdominante, ou, ainda, como subdominante menor de sua paralela (ver diagrama na Fig. 18, abaixo). (Frente à presumível objeção acerca da eficácia, no plano sensível, dessas triangulações, deve ficar claro que não se pretende, com elas, definir uma relação funcional unívoca e estável entre as duas tonalidades principais, nem tornar inteligíveis por meio da escuta essas múltiplas relações funcionais possíveis, mas carregar de sentidos diversos a relação, mais ampla, entre as duas tonalidades envolvidas em nosso ponto de partida. Dificilmente um leitor comum terá clareza de todos os significados e implicações de uma metáfora em um poema ou em um romance, mas ele provavelmente experienciará, ao longo da obra, sua cada vez mais densa carga semântica.) 


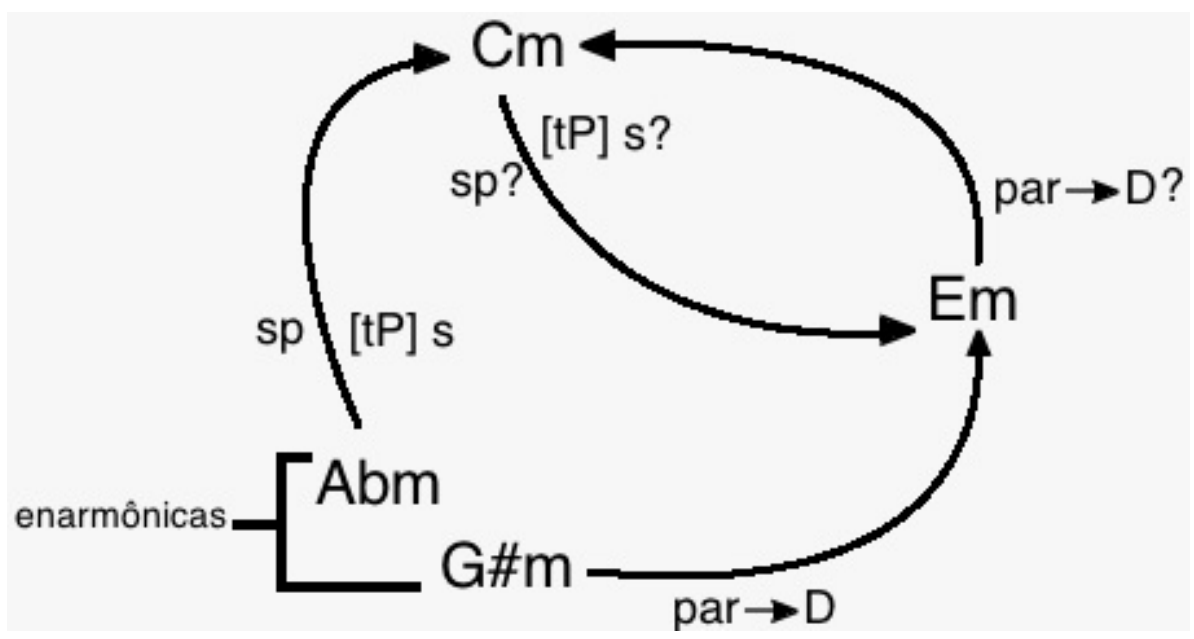

Fig. 18: Relações funcionais entre mediantes e submediantes desenhadas por meio das modulações a Lá bemol menor e a Sol\# menor. Usando uma notação funcional heterodoxa: "sp" corresponde à paralela menor da subdominante menor; "[tP] s", à subdominante menor da tônica paralela; "par -> D", à paralela da dominante.

Ainda outra estratégia para estabelecer conexões entre essas tonalidades de Dó menor e Mi menor foi inserir, deslocadas para o contexto de cada uma delas, estruturas acordais oriundas da outra. Assim, nos compassos 6 e 7, por exemplo, ao passar da região de Lá bemol menor à da paralela de Dó menor, inseri um arpejo enarmônico a um mi maior (dó bemol, lá bemol, fá bemol), funcionando aqui como uma napolitana de Mi bemol (ver Fig. 16, pouco acima); entre os compassos 11 e 12, por sua vez, aproveitei-me da correspondência enarmônica entre dó dominante e fá\# germânica (i.e., com quinta rebaixada, sétima, nona e sem fundamental) para que uma estrutura acordal com fundamental em dó - e que, no contexto de Dó, seria uma dominante de sua subdominante (tal como de fato o fora no c. 4; ver Fig. 15, acima) - protagonizasse uma modulação para Mi menor. Na mesma passagem, aliás, pude, com uma ligeira alteração cromática nesse arpejo de mi menor, incrustar-lhe algo enarmonicamente semelhante a um arpejo da paralela de Dó, mi bemol (ver Fig. 19, abaixo). Semelhantemente à função formal cumprida pela insistente recontextualização do motivo sol-si (descrita pouco acima), com esse procedimento de deslocamento viso não apenas enriquecer com novos sentidos cada um dos acordes aí envolvidos, mas também colocar as tonalidades em que eles se inserem como que em perspectiva; pontuar, através da radical mudança de sentido assumida por um dado elemento harmônico, as diferenças entre as luzes (as tonalidades) que a cada vez o iluminam.

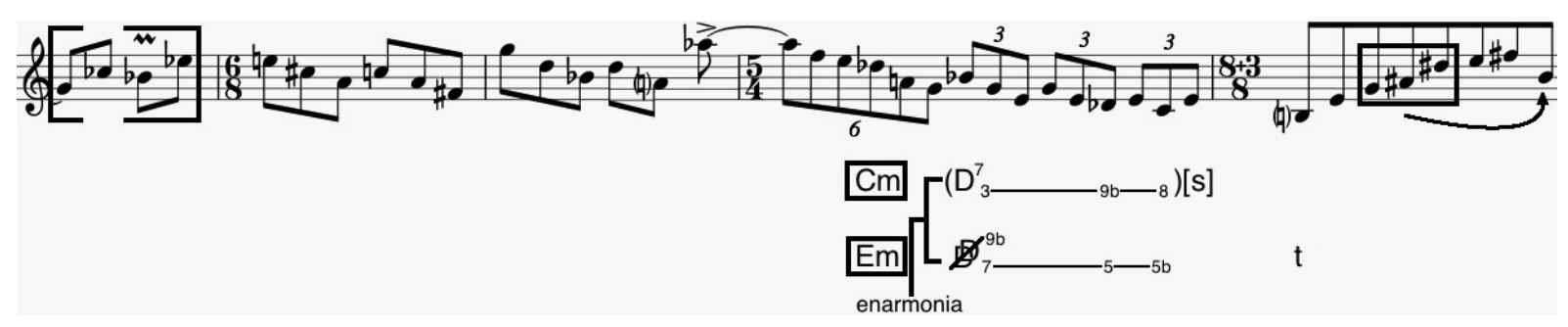

Fig. 19: Esboço dos c. 8-12. Estão assinalados, no c. 8, uma tríade tônica de mi bemol e, no c. 12, um fragmento enarmonicamente correspondente, em Mi menor. A seta assinala uma aproximação cromática a distância, e, sob a partitura, no c. 11, anoto as funções do acorde ambíguo aí aludido. 
Como se pode notar nos trechos mostrados até aqui, também a estrutura rítmica da peça é fortemente nutrida por aspectos do fragmento de partida, sobretudo por seu fluxo de colcheias, pela irregularidade ternária do final do c. 12 e pela figura da síncope do final do c. 13. Sobretudo nos primeiros compassos da peça, o desafio composicional foi, analogamente ao trabalho harmônico, criar contexto para que, quando da ocorrência daquele fragmento, esses aspectos tivessem já alguma carga, alguma história na peça. Assim, no fluxo inicialmente binário de colcheias, a irregularidade ternária foi gradualmente introduzida: primeiramente em um compasso composto, mas internamente regular - o 6/8 do c. 4 -; pouco em seguida, no c. 6, em um compasso internamente irregular, de 7/8; dominando a figuração dos c. 9 e 10 e; dissolvendo-se em tercinas rumo à modulação a Mi menor (ver Fig. 20b, abaixo). Quanto à figura de síncope, para além de abrir espaço para que o clarinetista respirasse em meio ao fluxo de colcheias, ela foi um recurso, por exemplo, para que o motivo sol-dó bemol ganhasse relevo no c. 6, ou para que, logo antes do c. 11, se criasse impulso para essa figuração tercinada. Na segunda parte (pós c. 15), tendo já em mãos uma relativa variedade rítmica produzida e estabelecida na primeira, pude lidar com essa dimensão mais livremente e criar jogos mais locais - como, por exemplo, a persistência do 7/8, como uma efêmera dança búlgara, aksak, nos c. 17-19 (Fig. 17, acima).

(a)

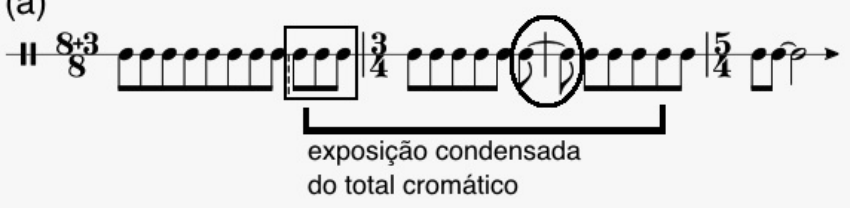

(b)

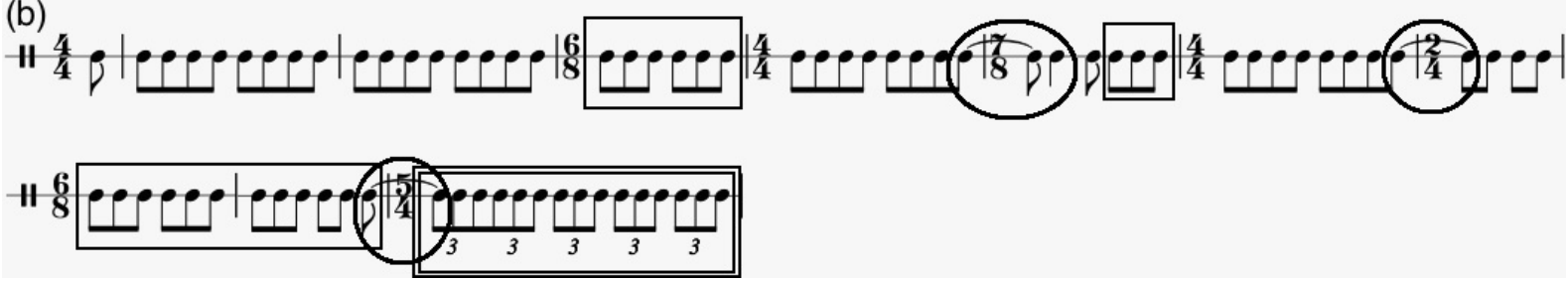

Fig. 20: (a) Esquema rítmico dos c. 12-15; (b) esquema rítmico dos c. 2-11. Para melhor visualização das correspondências entre os dois trechos e da direcionalidade dos compassos iniciais da peça: retângulos assinalam as células ternárias; retângulos duplos, as tercinas; e elipses, as síncopes.

Tendo basicamente, até esse ponto do processo composicional, duas partes em torno do fragmento de partida - em que uma primeira, em Dó menor, direcionava-se aos bemóis e uma segunda, em Mi menor, aos sustenidos -, pareceu-me que, a fim de cumprir na peça com um senso de encerramento formal, eu teria quatro tarefas em seu trecho final: 1) de algum modo conciliar os movimentos harmônicos divergentes das duas partes anteriores e dar à peça um senso de resolução harmônica - em especial, tendo iniciado a peça em Dó menor, compensar com um direcionamento aos bemóis o forte distanciamento, na segunda parte, rumo aos sustenidos -; 2) aproveitar e recombinar, de maneira ainda mais concisa, os vários procedimentos pelos quais se construíra a peça até então; 3) não deixar sozinha na peça a passagem que motivara sua composição e fazer esse último trecho culminar em uma passagem que lhe fosse semelhante, isto é, protododecafônica e modulatória; 4) emoldurar a peça com um último sol-si. 
Assim, partindo, nesse trecho final, uma vez mais de Dó menor, realizei uma modulação mirando não exatamente Mi menor, mais sustenida, mas, ao contrário, buscando alcançá-lo por meio de um movimento em direção à sua equivalente enarmônica, Fá bemol menor, tão distante de Dó menor, aliás, quanto o limite sustenido de Sol\# menor, que se alcançara no c. 20. (Na partitura, evidentemente, fiz a devida correção enarmônica, a partir do c. 27, a fim de evitar uma profusão de acidentes dobrados.) Mirando esse avesso lunar de Mi menor, cuidei, ademais, de que, nessa breve passagem, uma vez mais fossem apresentadas todas as demais notas do total cromático antes da própria tônica almejada (fá bemol/mi).
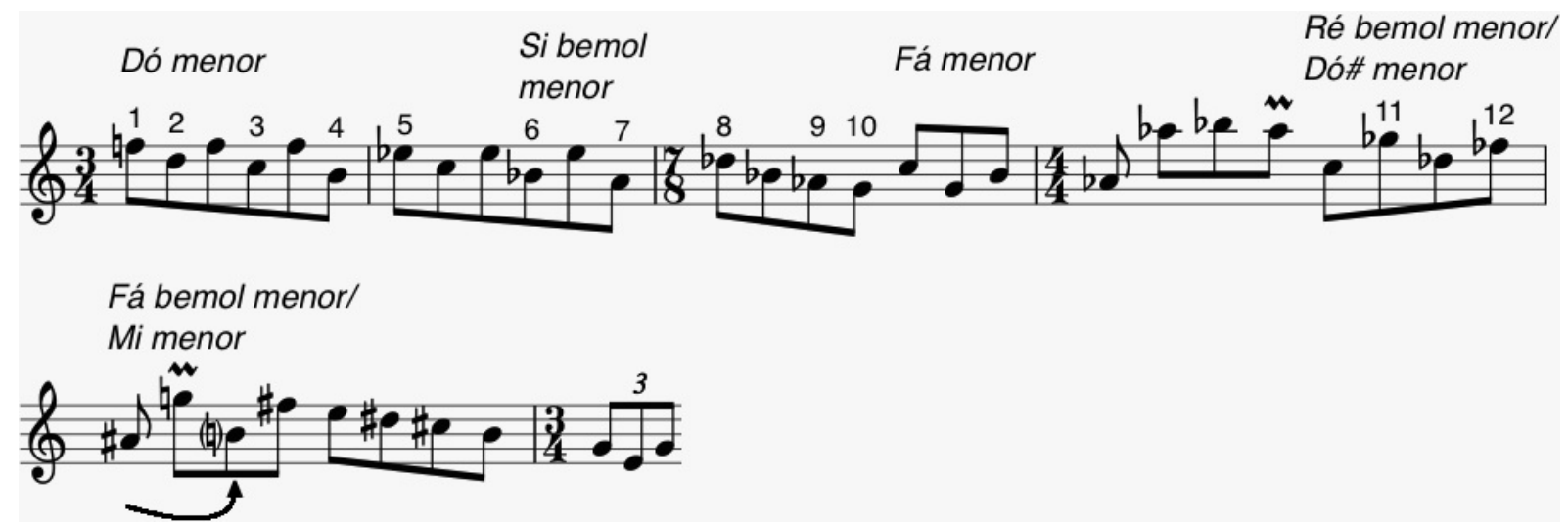

Fig. 21: Esboço dos c. 23-27, com indicação da primeira ocorrência de cada uma das doze notas e assinaladas as tonalidades aludidas a cada momento.

Na sequência, em paralelo àquela dominante híbrida do c. 11 - introduzida como um dó dominante, resolvida como um fá\# germânico -, uma figuração de tercinas, no c. 29, delineia mais claramente, agora, um fá\# dominante. Com uma menção à sua décima terceira (ré\#), pude também aqui, tal como no mi menor do c. 12, incrustar, deslocado de contexto, algo enarmonicamente semelhante a uma tríade da paralela (mi bemol) de Dó menor. Foi também ainda em meio a essa figuração tercinada que fiz apresentar-se o segmento em Mi menor de uma nova apresentação condensada, protododecafônica, do total cromático (ver Fig. 22, abaixo). Quanto ao segmento em Dó menor, ele deu o contexto para uma última ocorrência, agora invertida, do motivo sol-si. Delineando com as últimas notas da peça um sol dominante, pude fazer com que, ainda sem uma cadência em Dó - sem a ocorrência, em toda a peça, aliás, de uma única tríade tônica de Dó -, Dó menor se restabelecesse como uma tonalidade principal e, valendo-me ademais da figuração pendular, pude fazer com que o si, soando como uma resolução de suspensão (dó-si; quarta e terça do sol dominante) e alcançado descendentemente, portasse consigo - fechando a peça - um senso de repouso.

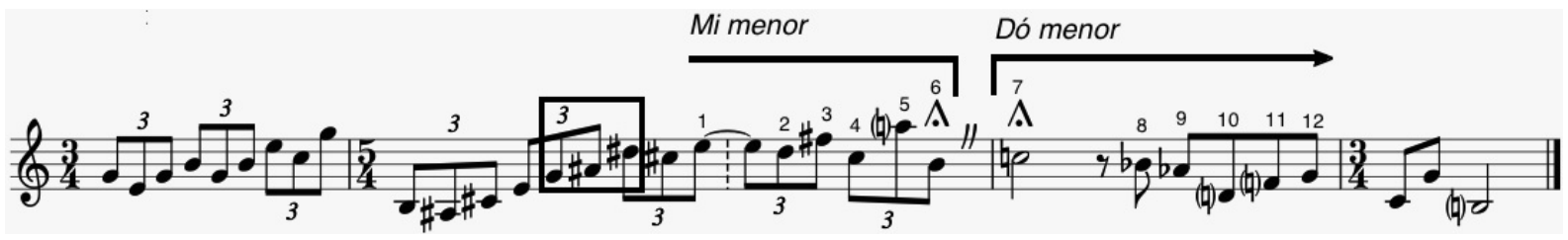

Fig. 22: Esboço dos c. 28-31, com indicação da nova apresentação condensada do total cromático. No c. 29, está assinalado um fragmento enarmonicamente correspondente à tríade de mi bemol, agora incrustado em um fá\# dominante. 
Para melhor visualização da estrutura da peça, transcrevo abaixo um diagrama que fiz durante o processo composicional (não antes!) para me guiar no encerramento da peça.

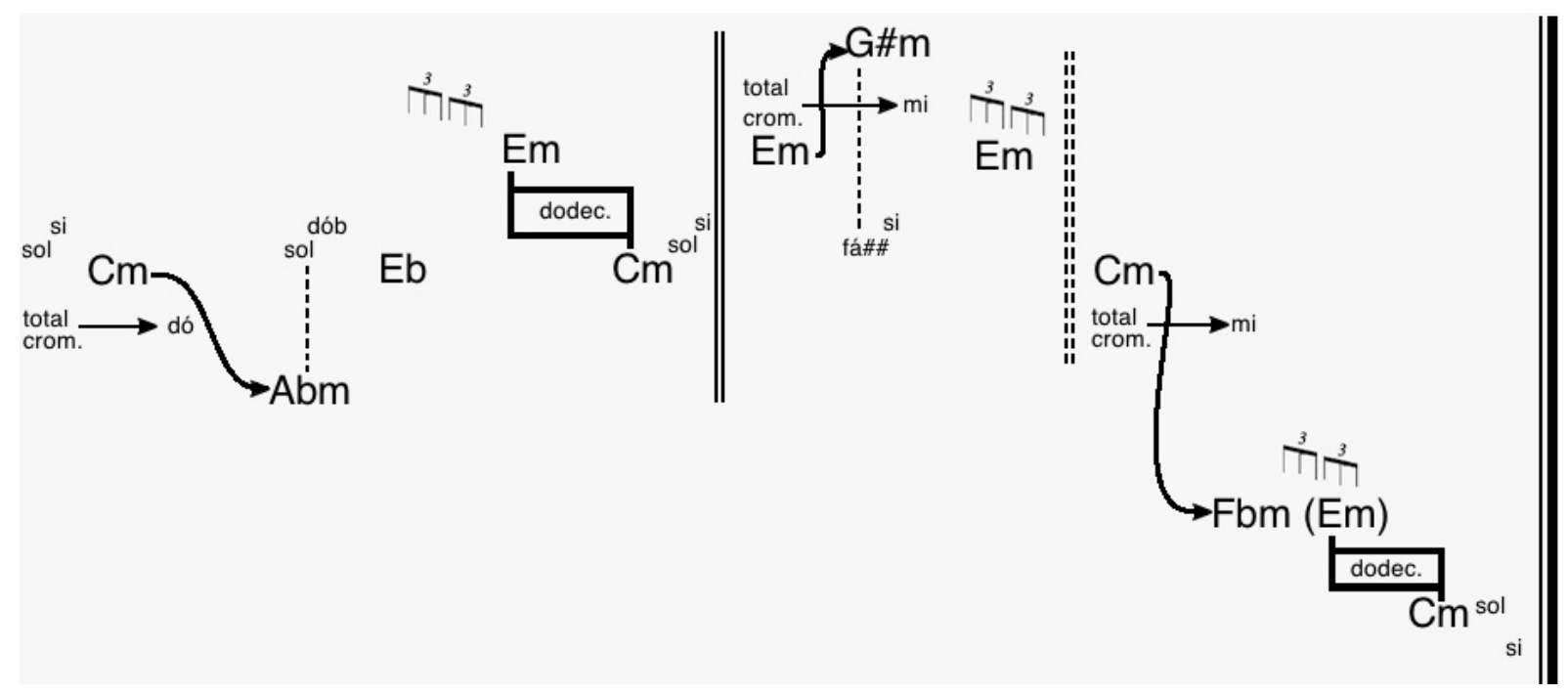

Fig. 23: Diagrama representando a forma da peça. Na horizontal, da esquerda para a direita, está representado o desenvolvimento da peça no tempo; na vertical, estão representadas, para cima, tonalidades mais sustenidas, e, para baixo, tonalidades mais bemóis.

\section{Considerações finais}

O que relatei, no presente artigo, foi um exemplo de processo de integração funcional. Tendo acima um diagrama com os principais traços da forma da peça e estando reproduzida, pouco abaixo, sua partitura, devemos agora lembrar que essa forma final da peça é quase inteiramente decorrente - direta ou indiretamente - da busca por imbuir aquele fragmento protododecafônico, a pedra lunar, de significado harmônico (funcionalidade) e relevância formal. Partindo de um objeto insólito (não para a Lua, é claro, mas certamente para o pomar), desenhei seu entorno - tornando assim pronunciadas as tonalidades por ele aludidas -, derivei traços da forma - desenvolvendo, por exemplo, essas duas tonalidades, fazendo-as triangular com outras mediantes e submediantes, buscando estabelecer um equilíbrio diacrônico entre essas várias regiões tonais - e dei corpo, aqui e ali, a passagens que tomavam emprestados seus processos formativos - como o novo fragmento protododecafônico do final, ou como cada um dos trechos em que o total cromático foi apresentado de maneira controlada.

A título de conclusão, considero alguns aspectos particularmente dignos de nota nesse processo de integração funcional. Em primeiro lugar - e no que diz respeito à própria atividade composicional, à conduta e à experiência aí envolvidas -, um tal processo propiciou uma relação constante de descoberta com a forma. A esse respeito, note-se, por exemplo, que a forma não foi dada aqui por nenhum modelo pronto; que ela tampouco estava determinada de antemão, em um momento composicional de pré-estruturação, e; ademais, que uma vez realizada, ela também não corresponde a 
qualquer modelo prévio. Note-se ainda, por outro lado, que ela não foi deixada à revelia e não se trata aqui de um resultado casual do processo composicional. Ao contrário, a integração funcional promoveu um processo formativo, de cunho dinâmico e heurístico, ora modulado por decisões composicionais mais locais, ora modulante destas; e resultou, ademais, em uma forma singular, peculiar a este processo composicional, e intimamente relacionada a um ponto de partida também singular.

Também a relação com a tonalidade, aqui, não é de cunho nostálgico, nem anedótico, mas, igualmente, de descoberta. Evidentemente, nenhum dos procedimentos que aqui lhe digam respeito é, em si, novo: nem a relação em larga escala entre mediantes cromáticas, nem a oposição entre regiões mais sustenidas e mais bemóis, nem a chegada a uma Tonart mais sustenida "pelo outro lado" do ciclo de quintas - de que há claros exemplos no Allegro da Sinfonia no 3 de Brahms (1883), para citar apenas uma obra sua. A relação de descoberta, aqui, se dá, por um lado, por se assumir a tonalidade e suas relações como contextuais, não unívocas, instáveis, abertas, difusas - note-se, por exemplo, a profusão de relações diferentes, não apenas funcionais, aqui exploradas entre as mediantes -, e, por outro, é claro, por pôr a tonalidade em relação com sua alteridade, incrustando-lhe o que the é insólito, percorrendo-a por processos vindos de fora e fazendo dela uma luz que incide sobre esse outro - fazendo dela um pomar que o cerca.

Em terceiro lugar, ressalto que não apenas no nível global, da forma, a integração funcional se faz centrada na dimensão processual da composição, mas também em nível local, porquanto o interesse primeiro não está nos traços, propriamente, do ponto de partida, mas nos procedimentos que o constituem ou que o poderiam ter constituído. Note-se, por exemplo, que a peça aqui apresentada não tem propriamente temas. Há nela a recorrência de um motivo extremamente sucinto e pouquíssimo característico; há a predominância de um movimento pendular, extremamente comum - como meio de gerar polifonia latente - há ao menos três séculos; há um tratamento quase motívico de células rítmicas também extremamente elementares - mas nada que se possa caracterizar como tema. O que, ao contrário, é aqui "tematizado", o que pontua os momentos de articulação formal e promove um senso de correspondência material entre as partes são, sobretudo, procedimentos: a enunciação condensada e controlada do total cromático, o estabelecimento de tonalidades por suas regiões vizinhas, as incursões às mediantes, o adensamento do movimento rítmico etc.

Finalmente, feita a ressalva de que a integração funcional exige o temperamento para que ela possa operar, devo pontuar que ela é um jogo composicional virtualmente inesgotável, porquanto os próprios meteoritos o são. Seu ponto de partida pode ser um fragmento melódico, como neste relato; pode ser um acorde incomum; mas pode ser também toda uma passagem musical, todo um trecho de uma peça anterior - de si ou de outrem -; pode ser, no limite, uma outra peça inteira. ${ }^{14}$ A quem se interessar por mais casos, há já alguns relatados na tese por trás deste artigo. ${ }^{15}$

\footnotetext{
14 Tange-se aqui a prática do comentário composicional, típica - mas não exclusiva - de Berio, que ademais a nomeou. Para um trabalho exaustivo e minucioso a esse respeito, ver Packer (2018). 


\section{II}
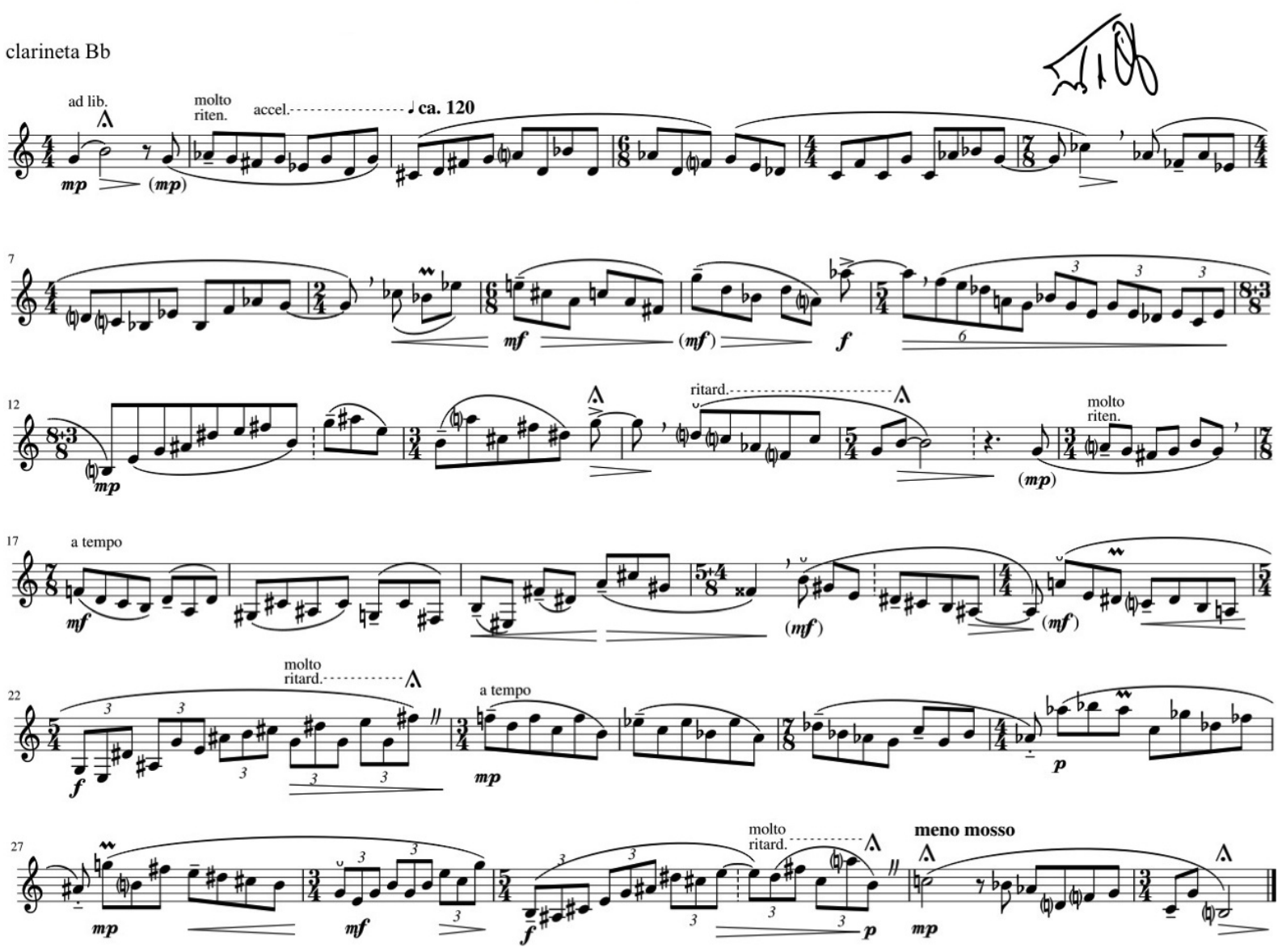

\section{Referências}

FERNEYHOUGH, B. Second String Quartet (1982). In: FERNEYHOUGH, B. Collected writings. Amsterdam: Harwood Academic Publishers, 1995. p. 117-130.

OLIVEIRA, F. Z. N. Tonalidade e seus desvios: reconhecimento e elaboração composicional de relações funcionais em meio a procedimentos harmônicos não funcionais. Tese (Doutorado) - Universidade de São Paulo, São Paulo, 2018. Disponível em: https://teses.usp.br/teses/disponiveis/27/27158/tde-27022019-153133/pt-br.php.

PACKER. M. Dobra, redobra, desdobra: comentário e abertura composicional de obras musicais. Tese (Doutorado) - Universidade de São Paulo, São Paulo, 2018. Disponível em: https://www.teses.usp.br/teses/disponiveis/27/27158/tde-11032019-113922/ptbr.php.

RIEMANN, H. Vereinfachte Harmonielehre oder die Lehre von den Tonalen Funktionen der Akkorde. London: Augener \& Co., [1893]. 
RIEMANN, H. Handbuch der Harmonie- und Modulationslehre (Praktische Anleitung zum mehrstimmigen Tonsatz). Berlin: Max Hesses Verlag, 1920.

ROSEN, C. Sonata forms. New York: W. W. Norton \& Company, 1980.

SCHOENBERG, A. Harmonielehre. Wien: Universal-Edition, 1922.

SCHOENBERG, A. Composition with Twelve Tones (1941/1948). In: SCHOENBERG, A. Style and idea. New York: Philosophical Library, 1950. p. 102-143.

SCHOENBERG, A. Gesinnung oder Erkenntnis (1926). In: SCHOENBERG, A. Stil und Gedanke. Aufsätze zur Musik. Frankfurt: S. Fischer, 1976. p. 209-214.

SCHOENBERG, A. Harmonia. Trad. Marden Maluf. São Paulo: Editora Unesp, 2001.

SCHOENBERG, A. Funções estruturais da harmonia. Trad. Eduardo Seincman. São Paulo: Via Lettera, 2004.

STOCKHAUSEN, K. et al. Stockhausen vs. the Technocrats. In: COX, C.; WARNER, D. (ed.). Audio culture: readings in modern music. New York: Continuum, 2004. 